\title{
Steroid hormones and chondrichthyan reproduction: Physiological functions, scientific research, and implications for conservation
}

\author{
Edgar Eduardo Becerril-García ${ }^{1}$, Marcial Arellano-Martínez ${ }^{\text {Corresp., } 1}{ }^{\text {, Daniela Bernot-Simon }}{ }^{2}$, Edgar Mauricio Hoyos- \\ Padilla $^{3,4}$, Felipe Galván-Magaña ${ }^{1}$, Céline Godard-Codding ${ }^{5}$ \\ ${ }^{1}$ Instituto Politécnico Nacional, Centro Interdisciplinario de Ciencias Marinas, La Paz, Mexico \\ 2 Departamento Académico de Ciencias Marinas y Costeras, Universidad Autónoma de Baja California Sur, La Paz, Mexico \\ 3 Pelagios Kakunjá A.C., La Paz, Mexico \\ 4 Fins Attached, Colorado Springs, United States \\ 5 The Institute of Environmental and Human Health, Texas Tech University, Lubbock, Texas, United States \\ Corresponding Author: Marcial Arellano-Martínez \\ Email address: arellano.marcial@gmail.com
}

The study of the reproductive aspects of chondrichthyans through the analysis of steroid hormones has been carried out for more than five decades in several species around the world. This scientific knowledge constitutes the basis of the reproductive endocrinology of chondrichthyans, which has provided information regarding their sexual maturation, gametogenesis, mating seasons, gestation periods, and parturition. The present review summarizes the existing literature on steroid hormones in chondrichthyan reproduction and identifies future research directions addressing critical knowledge gaps in the reproductive physiology of this taxon. A total of 59 peer reviewed scientific papers from 1963-2020 were reviewed and the following parameters analysed: species, steroid hormones, biological matrix, field sampling (year, location) and methodology (assays, sample size, precision, and recoveries). We provided a summary of the methods, biological matrices, and the functions of up to 19 hormones on the biology of 34 species of chondrichthyans that have been analysed to date. The majority of the studies used radioimmunoassay as the main methodology $(76.3 \% ; n=45)$; while the most frequent biological matrix used was plasma $(69.5 \% ; n=41)$. A Kernel's heat map was generated to present the scientific effort according to geographic location and evidenced a lack of research in high biodiversity areas for chondrichthyans worldwide. The implications of the study of steroid hormones for the conservation of chondrichthyans are discussed, as only $2.9 \%$ of the species of this group have been analysed and most of the scientific effort (93.2\%; $n=55 / 59$ papers) has focused on the analysis of less than six hormones. 


\section{Steroid hormones and chondrichthyan reproduction:}

2 Physiological functions, scientific research, and

3 implications for conservation

5 Edgar Eduardo Becerril-García ${ }^{1}$, Marcial Arellano-Martínez ${ }^{1}$, Daniela Bernot-Simon ${ }^{2}$, Edgar

6 Mauricio Hoyos-Padilla ${ }^{3,4}$, Felipe Galván-Magaña ${ }^{1}$, Céline Godard Codding ${ }^{5}$ 7

$8{ }^{1}$ Instituto Politécnico Nacional, Centro Interdisciplinario de Ciencias Marinas, La Paz, Mexico.

$9 \quad{ }^{2}$ Departamento Académico de Ciencias Marinas y Costeras, Universidad Autónoma de Baja

10 California Sur, La Paz, Mexico.

$11{ }^{3}$ Pelagios Kakunjá A.C., La Paz, Mexico.

$12{ }^{4}$ Fins Attached, Colorado Springs, USA

135 The Institute of Environmental and Human Health, Texas Tech University, Lubbock, USA. 14

15 Corresponding Author:

16 Marcial Arellano-Martínez ${ }^{1}$

17 Av. Instituto Politécnico Nacional S/N, La Paz, BCS, 23096, Mexico

18 Email address: arellano.marcial@gmail.com 


\section{Abstract}

21 The study of the reproductive aspects of chondrichthyans through the analysis of steroid

22

23

24

25

26

27

28

29

30

31

32

33

34

35

36

37

38

39

40

41

42

43

44

45

46

47

48

49

50

51

52

53

54

55

56

57

58

59

hormones has been carried out for more than five decades in several species around the world. This scientific knowledge constitutes the basis of the reproductive endocrinology of chondrichthyans, which has provided information regarding their sexual maturation, gametogenesis, mating seasons, gestation periods, and parturition. The present review summarizes the existing literature on steroid hormones in chondrichthyan reproduction and identifies future research directions addressing critical knowledge gaps in the reproductive physiology of this taxon. A total of 59 peer reviewed scientific papers from 1963-2020 were reviewed and the following parameters analysed: species, steroid hormones, biological matrix, field sampling (year, location) and methodology (assays, sample size, precision, and recoveries). We provided a summary of the methods, biological matrices, and the functions of up to 19 hormones on the biology of 34 species of chondrichthyans that have been analysed to date. The majority of the studies used radioimmunoassay as the main methodology $(76.3 \%$; $n=45)$; while the most frequent biological matrix used was plasma $(69.5 \%$; $n=41)$. A Kernel's heat map was generated to present the scientific effort according to geographic location and evidenced a lack of research in high biodiversity areas for chondrichthyans worldwide. The implications of the study of steroid hormones for the conservation of chondrichthyans are discussed, as only $2.9 \%$ of the species of this group have been analysed and most of the scientific effort $(93.2 \% ; n=55 / 59$ papers) has focused on the analysis of less than six hormones.

\section{Introduction}

In recent decades, the study of hormones has greatly advanced our understanding of the reproductive biology of vertebrates. Most of the studies regarding steroid hormones in terrestrial and marine species have focused on three sex steroids: $17 \beta$-oestradiol (E2), testosterone (T) and progesterone (P4; Idler 2012). These steroids are related to important reproductive processes such as spermatogenesis, oogenesis, the offset of sexual maturity and the maintenance of pregnancy in marine mammals, sea birds, and fishes (Idler 2012; Awruch 2013; Hayden et al. 2017). Analyses were performed primarily on captive or dead organisms, due to their invasive or lethal nature and the limitations of sampling free-ranging individuals. As a result, large knowledge gaps in reproductive physiology and endocrinology remain for several marine species, including vulnerable and ecologically important taxa such as sharks, rays, and chimaeras, collectively known as chondrichthyans (Hammerschlag and Sulikowski 2011; Maruska and Gelsleichter 2011; Awruch 2013).

Chondrichthyans are characterised by the presence of a cartilaginous skeleton, the lack of a swim bladder and internal fertilization (Compagno et al. 2005). The class Chondrichthyes includes more than 509 species of sharks, 630 rays and 49 chimaeras and comprises oviparous, as well as placental or aplacental viviparous species (Hamlett 2011; Castro et al. 2016; Weigmann, 2016). The range of reproductive biology strategies observed in this high diversity of species and 
60

61

62

63

64

65

66

67

68

69

70

71

72

73

74

75

76

77

78

79

80

81

82

83

84

85

86

87

88

89

90

91

92

93

94

95

96

97

98

99

associated habitats reflects different metabolic processes that have evolved for more than 400 million years (Compagno et al. 2005; Maruska and Gelsleichter 2011; Gelsleichter and Evans 2012; Castro et al. 2016).

Information provided by endocrinology studies regarding the mechanisms of sexual maturity, mating, gestation and parturition seasons of chondrichthyan populations, particularly for species relevant to fisheries and ecotourism, is essential for the economy of several countries around the world (Awruch 2013; Cisneros-Montemayor et al. 2019). The present review provides practical information regarding the steroid hormones studied in chondrichthyans, with a focus on the number of species and the type of reproduction, methodologies, biological matrices, and steroid panels analysed to date. Additionally, the scientific effort and the implications of steroids for the conservation of chondrichthyans are discussed to provide insights about new alternatives for the study of hormones in protected and non-protected species.

\section{Survey methodology}

Literature related to steroid hormones in the reproduction of chondrichthyans was obtained from several sources including Google Scholar, Web of Science, university and research centre websites, as well as scientific journal libraries using key words such as steroid, hormone, reproduction, and shark, ray or chimaera. From this search, a total of 1,630 results were obtained and checked for suitability according to the aims of the present review. Only peer reviewed papers were considered, resulting in 59 scientific articles and short communications that were published between 1963 and 2020. Data from each paper was extracted in order to classify the species involved, sex, analysed hormones, physiological function, year of study, location, tissue or biological matrix, used method, original volume per sample, body area for sample collection, sample size and reported recoveries. These data were presented in histograms while the location and scientific effort were analysed using a Kernel distribution heat map with the software QGIS v. 3.10.2. Additionally, the species reproductive mode, taxonomy and conservation status were determined according to Compagno et al. (2005), Castro et al. (2016), Froese and Pauly (2019) and the IUCN Red List of Threatened Species (2020).

\section{ANALYSED SPECIES}

Reproductive steroid hormones analyses were reported in a total of 34 chondrichthyans, including 21 sharks, 12 batoids and one chimaeriform (Table 1). Half of the reviewed studies included both males and females in their analysis $(45.8 \% ; n=27)$, while $37.3 \%(n=22)$ described only females and $16.9 \%(n=10)$ solely males. This scientific effort spanned the description of diverse reproductive strategies observed in chondrichthyans, including 22 viviparous (64.7\%) and 12 oviparous species (35.3\%; Fig. 1a).

Embryonic nutrition is related to the reproductive cycle of viviparous elasmobranchs and explains the varied endocrinology observed within this taxon (Maruska and Gelsleichter 2011). 
100 Embryos of viviparous species could complete their development through a placental connection,

101

102

103

104

105

106

107

108

109

110

111

112

113

114

115

116

117

118

119

120

121

122

123

124

125

126

127

128

129

130

131

132

133

134

135

136

137

138 ingestion of unfertilized oocytes or other embryos, yolk sac, or nutritional substances provided in histotrophic and embryotrophic species (Compagno et al. 2005; Hamlett 2011; Castro et al. 2016; Nelson et al. 2016). However, the number of studies is highly limited in certain groups, with few papers published for some reproductive modes such as oophagy (Carcharodon carcharias; Sulikowski et al. 2012), embryotrophy (Galeocerdo cuvier; Sulikowski et al. 2016) and adelphophagy (C. taurus; Henningsen et al. 2008; Wyffels et al. 2019).

Sex steroids have been studied in oviparous chondrichthyans since 1979, including in six species of sharks, five species of rays and the spotted ratfish Hydrolagus colliei as the only chimaera (Table 1). The 18 papers published to date constitute the basis of the scientific knowledge of the reproductive endocrinology of oviparous chondrichthyans, providing some insights regarding capsule protein synthesis, sperm storage and oviposition (Sumpter and Dodd 1979; Awruch et al. 2009; Barnett et al. 2009; Nau et al. 2018).

To date, there is no general pattern that could describe the specific actions of sex steroids in chondrichthyans, mainly due to the high diversity of species in this group and the few number of comprehensive and detailed research involving specimens in captivity(Anderson et al. 2018). The lack of a general pattern is probably due to the variety of embryonic nutrition strategies presented in the group, the overall paucity of species investigated as well as inherent differences between species, localities, and individuals (Compagno et al. 2005; Awruch 2013; Nelson et al. 2016). In a general perspective, sex steroids have been described in only $2.9 \%$ of the 1,188 living species of chondrichthyans (Weigmann 2016). Although previous studies have allowed the partial description of the endocrinology in multiple reproductive strategies (Table 1), the proportion of species analysed to date for their steroid hormones is scarce compared to the ecological richness of this taxonomic class. For instance, only $4.1 \%$ of the total of sharks, $1.9 \%$ of batoids, and $2.0 \%$ of chimaeras are represented (Weigmann, 2016).

The majority of the analysed taxa constitute marine resources for artisanal and industrial fisheries in several localities around the globe (Compagno et al. 2005; Nelson et al. 2016). The use of commercial species as biological models has allowed the analysis of both gonads and blood as well as the improvement of methods for the detection of steroid hormones. Elasmobranch species listed as "Least Concern", such as the small-spotted catshark Scyliorhinus canicula, the bonnethead shark Sphyrna tiburo and the round stingray Urobatis halleri are examples of such biological models (Table 2). The large number of steroid hormones analysed in these chondrichthyans species improved our understanding of the reproductive endocrinology of this group, particularly in terms of sexual maturation, gametogenesis and gestation (Sumpter and Dodd 1979; Manire et al. 1999; Mull et al. 2008; Lyons and Wynne-Edwards 2019).

Peer] reviewing PDF | (2020:04:47925:2:0:NEW 15 Jul 2020) 
139 Analyses involving lethal methods on commercial species has partially been used as a

140 comparison or baseline when studying threatened species. In this regard, a third of the analysed

141 chondrichthyans are considered vulnerable or endangered according to the IUCN (2020),

142 although this status is not always associated with their protection (Fig. 1b). Some of the analysed

143 species pertaining to economic activities other than fisheries such as ecotourism are the white

144 shark C. carcharias, the whale shark Rhincodon typus and the reef manta ray Mobula alfredi.

145 However, only the study of $C$. carcharias carried out by Sulikowski et al. (2012) has involved

146 the description of hormonal levels in a wild population through invasive practices, while the

147 studies of whale sharks and manta rays have been made in captivity (Nozu et al. 2015, 2017;

148 Matsumoto et al. 2019). Even though these and other species are relevant for ecotourism

149 worldwide, available information about their reproduction remains scarce for numerous

150 populations (Huveneers et al. 2018; Cisneros Montemayor et al. 2019).

151

152

153

154

155

156

157

158

159

160

161

162

163

164

165

166

167

168

169

170

171

172

173

174

175

176

177

\section{METHODS AND BIOLOGICAL MATRICES}

The study of steroid hormones in the reproduction of chondrichthyans has been carried out using five analytical methods (Fig. 2a) that can be grouped in two main categories: 1) immunoassaybased including radioimmunoassay (RIA), enzyme immunoassay or enzyme-linked immunosorbent assay (EIA/ELISA), and time-resolved fluorescent immunoassay (TRFIA); and 2) physical separation-based including paper chromatography or thin layer chromatography followed by gas chromatography (PC/TLC-GC), and liquid chromatography coupled with triple quadrupole tandem mass spectrometry and electrospray ionization with multiple reaction monitoring (LC-MS/MS). In the case of immunoassays, a diverse number of antibodies have been used, particularly polyclonal full serum antibodies raised in mammals or amphibians for E2, T, and P4 (Tosti et al. 2006, Awruch et al. 2009; Hoffmayer et al. 2010; Nau et al. 2018). However, antibodies for relevant steroids such as $1 \alpha$-hydroxycorticosterone were not available at the time of study (Rasmussen and Gruber, 1993). A brief description of the methods used and their applications in chondrichthyans is presented below:

RIA. Assay based on antigen-antibody complex and radioactively labelled antigens (Goldsmith 1975). This immunoassay methodology was first carried out in chondrichthyans by Sumpter and Dodd (1979) using the plasma of S. canicula. Since then, RIA have analysed an average of 3.36 (S.D. \pm 1.31 ) steroid hormones per paper (Fig. 3) with hormone recoveries ranging from 17-111\% (Table 2). Minimum and maximum number of specimens were 2-248 for males (Tricas et al. 2000; Sulikowski et al. 2016) and 1-248 for females (Rasmussen and Murru 1992; Tricas et al. 2000). From the reviewed studies, only $61.7 \%$ specified the polyclonal antibodies used. A total of 28 species of chondrichthyans have been analysed through RIA, including 17 sharks, 10 rays and one chimaera (Table 2). This biochemical assay was used in $76.3 \%(\mathrm{n}=45)$ of the 
178

179

180

181

182

183

184

185

186

187

188

189

190

191

192

193

194

195

196

197

198

199

200

201

202

203

204

205

206

207

208

209

210

211

212

213

214

215

216

217

reviewed studies, making RIA the most widely used technique for the study of steroid hormones in these group of cartilaginous fishes (Fig. 2a).

EIA/ELISA. Biochemical assay techniques focused on the detection and quantification of a wide range of substances including antibodies, allergens, proteins, peptides, hormones, etc. (Vashist and Luong 2018). These biochemistry assays were first used to describe steroid hormones in the plasma of the spotted ray Torpedo marmorata (Prisco et al. 2008), and subsequently in the Atlantic sharpnose shark Rhizoprionodon terranovae (Hoffmayer et al. 2010). Since then, it has been used for the study of captive endangered species by analysing semen of the whale shark R. typus (Nozu et al. 2015) and plasma of the reef manta ray Mobula alfredi (Nozu et al. 2017) and zebra shark Stegostoma fasciatum (Nozu et al. 2018). The studies that have applied EIA/ELISA detected an average of 2.62 (S.D. \pm 1.06 ) steroid hormones per paper with recoveries of $85-108 \%$ (Fig. 3). Minimum and maximum number of specimens were 2-81 for males (Nozu et al. 2017; Wyffels et al. 2019) and 3-94 for females (Nozu et al. 2015; Mylniczenko et al. 2019). All papers with EIA/ELISA as the main analytical method mentioned the antibodies used and constitute $13.6 \%(n=8)$ of the reviewed literature.

TRFIA. This non-radioactive immunoassay involves the use of Europium labelled antibodies and antigens for the detection of substances along with a fluorometer for the quantification through means of lanthanide fluorescence (Diamandis 1988). In chondrichthyans it was used by Matsumoto et al. (2019) for the analysis of T and P4 in plasma of a captive whale shark. The monitoring for 20 years of this young male allowed to describe the effect of $\mathrm{T}$ and $\mathrm{P} 4$ on the sexual maturation of this endangered species, since an increase of T and P4 was related to the morphogenesis and functioning of claspers. The antibodies used in this paper were not specified. This study constitutes $1.7 \%$ of the reviewed papers.

PC/TLC-GC. Physical techniques for the separation of components from a specific solution trough a stationary and a moving phase, which is paper and a liquid solvent in PC and silica plates interacting with liquids or gas in TLC and GC, respectively (Bhawani et al 2010). PC was first reported for steroid hormones in chondrichthyans by Simpson et al. $(1963,1964)$ in semen of S. canicula. In the study of Di Prisco et al. (1967), the analysis of plasma of T. marmorata allowed the detection of eight sex steroid by using TLC-GC (Table 2). The studies that have required this technique have analysed an average of 3.36 (S.D. \pm 1.68 ) steroids per paper (Fig. 3). Recoveries of steroid hormones ranged from 34-65\% depending on the author (Table 2). Minimum and maximum number of specimens were 5-40 for males (Simpson et al. 1964; Gottfried and Chieffi 1967) and 38 for females (Di Prisco et al. 1967). These methodologies were mostly used during the sixties and constitute $6.8 \%(n=4)$ of the reviewed studies.

Peer] reviewing PDF | (2020:04:47925:2:0:NEW 15 Jul 2020) 
218

219

220

221

222

223

224

225

226

227

228

229

230

231

232

233

234

235

236

237

238

239

240

241

242

243

244

245

246

247

248

249

250

251

252

253

254

255

256

257
$L C-M S / M S$. This method combines chromatography and mass spectrometry for the separation and quantification of a wide range of substances including most organic compounds (large proteins, pollutants, drugs, and hormones; Wudy et al 2018). It was recently used by Lyons and Wynne-Edwards (2019) for the simultaneous analysis of 13 steroid hormones in plasma and histotroph samples of the round stingray $U$. halleri. While some of these steroids were below the limit of quantification for selected samples, this was the study with the highest number of detected hormones overall. However, this paper did not report recoveries of the extracted steroids from the tissues of the 55 female specimens analysed. This technique was used only in this study and constitutes $1.7 \%$ of the reviewed papers.

The above methodologies used for the detection and quantification of steroid hormones were applied to six biological matrices: blood (plasma or serum), semen, yolk, histotroph, gonads and muscle. Most studies were performed using plasma $(69.5 \% ; n=41$ papers $)$ or serum $(13.6 \% ; n=8$ papers), with three studies including semen $(5.1 \% ; n=3$ papers) and seven papers involved the analysis of other matrices (11.9\%; Fig. 2b). In the case of blood, the original volume per sample ranged between $0.5-20 \mathrm{~mL}$, while the volume for analysis was $25-1000 \mu \mathrm{L}$ (Table 2). Other tissues such as muscle or gonad required approximately 3-5 g of the original sample for hormone extraction (Prohaska et al. 2013a) and $19 \mathrm{~g}$ in the case of semen (Gottfried and Chieffi 1967). In the majority of the studies, the obtention of samples in these quantities was met through the sacrifice of specimens, or through the interaction with captive elasmobranchs.

The sample mass required for the extraction of hormones in tissues like blood, gonad, histotroph and yolk usually entailed the use of a lethal methodology in $69.0 \%(n=40)$ of the analyses (Fig. 2b). Most blood studies included sample collection carried out through cardiac, caudal, or dorsal venepuncture (Table 2). Studies that did not required a lethal methodology $(31.0 \% ; n=18)$ were considered invasive due to the capture or manipulation needed for the collection of samples. In addition to extraction kits, the main methods for hormones analyses in chondrichthyans were solvent/ether extractions using diethyl ether, ethyl acetate, and petroleum ether; although other substances such as chloroform: methanol, dichloromethane, ethyl acetate/cyclohexane, and benzene ether were also used (Table S1).

Some of the first papers that described steroid hormones in tissues other than blood were carried out via PC/TLC-GC by Simpson et al. (1963, 1964) and Gottfried and Chieffi (1967) using semen of Squalus acanthias and S. stellaris, respectively. More than two decades later, analyses of histotroph, gonads and plasma from S. canicula and T. marmorata were performed via RIA (Fasano et al. 1992; Garnier et al. 1999). Analyses of steroid hormones from yolk were only studied in S. tiburo by RIA (Manire et al. 2004). The use of skeletal muscle was first analysed by Barnett et al. (2009) and further by Prohaska et al. (2013a), both via RIA. The latter suggested

Peer) reviewing PDF | (2020:04:47925:2:0:NEW 15 Jul 2020) 
258 the use of muscle as an alternative for the study of protected elasmobranchs, since a correlation

259 between steroid concentrations in plasma and muscle was observed (Hammerschlag and

260 Sulikoswki, 2011; Prohaska et al. 2013a).

261

262

263

All the analysed steroids used for reproductive assessment according to each biological matrix

264 are detailed in Table 2. The average number of steroid hormones analysed per study that used

265 plasma was 3.3 (S.D. \pm 1.7); 4.2 (S.D. \pm 1.2 ) for serum; 5.3 (S.D. \pm 3.2) for gonad; 1.3 (S.D. \pm

266

267

268

269

270

271

272

273

274

275

276

277

278

279

280

281

282

283

284

285

286

287

288

289

290

291

292

293

294

295

296 0.6 ) for semen; 3.0 for muscle and 7.0 (S.D. \pm 4.2 ) for histotroph. To date, most of the studies have focused on the analysis of several tissues using immunoassay-based methods such as RIA or ELISA/EIA and therefore the antigen-antibody complex interaction (Fig. 2a). Overall, the results from these analyses of the six biological matrices in several species are the current basis of the endocrinological knowledge of chondrichthyans in terms of reproductive biology. This scientific effort has allowed the detection and quantification of a wide diversity of steroid hormones and furthered the knowledge of their role in the reproduction of these cartilaginous fishes.

\section{STEROID HORMONES AND REPRODUCTIVE BIOLOGY}

Since 1963, a total of 19 steroid hormones have been detected in six biological matrices from 34 species of chondrichthyans (Table 3). The analysed steroids comprise six androgens including $\mathrm{T}$, $5 \alpha$-dihydrotestosterone (DHT), 11-ketotestosterone (11-KT), androstenedione (A4), 11ketoandrostenedione (11KA), and $5 \alpha$-androstane- $3 \alpha, 17 \beta$-diol ( $3 \alpha$-diol); four progestogens: P4, 17-hydroxyprogesterone (17-OHP), dihydroprogesterone (DHP), and 17-hydroxypregnenolone (17P5); three oestrogens: estrone (E1), E2, as well as estriol (E3); four glucocorticoids: corticosterone (CORT), cortisone (E), cortisol (F), and 11-deoxycortisol (S); and 11deoxycorticosterone (DOC) and 11-dehydrocorticosterone (11-DHC) as the only two mineralocorticoids (Idler 2012; Melmed 2015; Fig. 4).

Ten of these 19 steroids were quantified in blood and nine in gonads, including the detection of 3a-diol solely in the testes of S. canicula (Fasano et al. 1992; Garnier et al. 1999). The use of LC-MS/MS allowed the simultaneous detection $\mathrm{n}$ of 13 of such steroids in both plasma and histotroph (Lyons and Wynne-Edwards 2019; Table 2). Other matrices such as semen allowed the detection of steroid hormones not found in blood, gonads or histotroph, such as 17P5 (Gottfried and Chieffi 1967). In recent RIA studies, the use of skeletal muscle has allowed the detection of P4, T and E2 in the sharks S. acanthias and R. terranovae (Prohaska et al. 2013a).

According to the reviewed literature, a brief summary of the functions of steroid hormones in the reproduction of chondrichthyans, biological matrices and methods is provided below. These descriptions constitute a general summary of the observations published to date; therefore, 
297 298 299 300 301 302 303 304 305 306 307 308 309 310 311 312 313 314 315 316 317 318 319 320 321

specific functions of each steroid should be considered for each species, as differences between reproductive strategies, sexes, and similar taxa have been reported.

Testosterone $(T)$. High concentrations of this androgen have been related to follicle development and to the maintenance of spermatozoa along with E2 in females (Manire et al. 1999; Tricas et al. 2000). Additionally, an increase of T was observed during the mating seasons of several elasmobranchs, suggesting that this steroid could play an important role in their reproductive ethology (Rasmussen and Gruber 1993; Manire et al. 1995; Garnier et al. 1999; Mull et al. 2010). In males, several studies described an increase of this androgen during spermatogenesis and sperm transportation, which could indicate a role in the maturation and motility of gametes (Heupel et al. 1999; Sulikowski et al. 2005). Additionally, T could be an anabolic agent for the growth of testes, reproductive ducts, and claspers (Sulikowski et al. 2005; Lyons and Wynne-Edwards 2019). In contrast to other vertebrates, knowledge regarding the functions of $T$ in the body or in the development of gonads is still scarce (Awruch 2013). This androgen has been quantified in six biological matrices using the five analytical methods described in this paper. A total of 52 papers have included $\mathrm{T}$ in their analyses, which constitutes $88.1 \%$ of the reviewed literature (Table 2).

5a-dihydrotestosterone (DHT). In chondrichthyans, DHT has been suggested as an important steroid for spermatogenesis along with $\mathrm{T}$ as a possible precursor of E2 (Manire et al. 1997; Tricas et al. 2000; Awruch 2013). However, there is no evidence regarding an aromatization of DHT into oestrogens such as E2, so this hypothesis is unlikely. In terms of steroid synthesis control, Tricas et al. (2000) suggested that DHT could provide an inhibitory feedback in the production of gonadotropin-releasing hormone $(\mathrm{GnRH})$, based on their observations in the ray H. sabinus. Additionally, an increase of DHT and T was observed during ovulation and later during histotroph nourishment. This could suggest that the action of DHT is related to the sexual differentiation in batoids as observed in other vertebrates (Tricas et al. 2000; Lyons and Wynne-Edwards 2019). In viviparous sharks such as $S$. tiburo, DHT was related to reproductive behaviour as the highest concentration of this steroid occurred during preovulation and mating stages (Manire et al. 1995). DHT was detected and quantified in blood, gonads and histotroph of elasmobranchs using RIA and ELISA (Table 2). There are no detections of DHT in holocephans to date. From the reviewed literature, a total of 13 papers $(22.0 \%)$ have included this steroid in their analyses (Table 2).

11-ketotestosterone (11-KT). In female elasmobranchs, 11-KT may play a role in the synthesis of oestrogens and ovarian follicle development, although most of the research has been focused on males (Manire et al. 1999). In this regard, a higher concentration of 11-KT could favour the sexual development of juvenile males, with an increase during 
363

364

365

366

367

368

369

370

371

372

373

374

375

376

the peak of sperm storage influencing sperm maturation and preparation for mating (Garnier et al. 1999; Mull et al. 2008). This androgen showed a negative correlation with photoperiod in specimens of $U$. halleri with levels of $11-\mathrm{KT}$ decreasing with daylight. The effect of light on the synthesis of some steroid hormones such as 11-KT could explain differences in sexual segregation regarding depth and habitat use for males, although research in this topic remains scarce. In holocephans, levels of 11-KT were $300 \%$ higher during pre-parturition stages, which suggest that this steroid could be related not only to parturition, but to sexual behaviour favouring the next reproductive cycle (Barnett et al. 2009). In general, it is likely that 11-KT is involved in the sexual maturity and mating behaviour of male chondrichthyans, although more research is needed in order to understand the exact role in their development and further reproduction. 11-KT has been detected and quantified in blood, gonads and muscle of chondrichthyans using RIA (Table 2). From the reviewed literature, a total of six papers $(10.2 \%)$ have included $11-\mathrm{KT}$ in their analyses (Table 2 ).

Androstenedione (A4). In batoids, A4 was higher during the greater fertile period and early gestation of $R$. bonasus, while there were no differences in A4 along with E2 in the analysed males (Sheldon et al. 2018). A similar increase was observed in early and midterm females just before the appearance of claspers in embryos of the round stingray $U$. halleri, which could suggest an intermediary role for sex differentiation along with 17OHP (Lyons and Wynne-Edwards, 2019). In contrast, the concentrations detected in $S$. canicula demonstrated an increase before a peak in sperm reserves, and A4 was consistently detected in the testis as one of the principal steroids along with T and P4 (Garnier et al. 1999). A4 has been quantified in plasma and testis of S. canicula and in the plasma of both sexes of $R$. bonasus using RIA, as well as in the histotroph of $U$. halleri (Table 2). Three papers (5.1\%) included A4 in their analyses (Table 2).

11-ketoandrostenedione (11KA4). This steroid was detected in serum of S. tiburo using RIA and appears only in the study of Manire et al. (1999). It is possible that an increase in 11KA4 plays a role in sperm storage and in the maintenance of pregnancy in viviparous species, as the concentrations rise from mating until prior to parturition. In males, the function of $11 \mathrm{KA} 4$ is unclear, as levels appear to be similar throughout the annual study periods in mature individuals. Further research involving different maturity stages could provide the first insights regarding the role of 11KA4 in most chondrichthyans. The paper of Manire et al. (1999) constitutes $1.7 \%$ of the reviewed literature.

$5 \alpha$-androstane-3 $\alpha, 17 \beta$-diol ( $3 \alpha$-diol). This hormone was quantified throughout the year in plasma and testis of $S$. canicula with significantly higher concentrations during winter, just prior to an increase in steroid hormones such as E2, E1, DHT,11-KT and a peak in 
sperm reserves (Garnier et al. 1999). While 3 $\alpha$-diol may play a role in the preparation of spermatogenesis, the metabolism of this steroid and its effects on the reproduction of chondrichthyans remain unclear. The paper of Garnier et al. (1999) used RIA as the analytical method and constitutes $1.7 \%$ of the reviewed literature.

Progesterone (P4). In females, this progestogen was suggested to act as an antagonist of E2 and consequently decrease the synthesis of vitellogenin in the liver (Tsang and Callard 1987; Tricas et al. 2000; Prisco et al. 2008; Mull et al. 2010). An increase of P4 along with 11KA4 could be related to the beginning and maintenance of pregnancy in viviparous species since the concentration of these hormones drop prior to parturition (Manire et al. 1999; Mull et al. 2010). In contrast, it is possible that a decrease in P4 is related to the regulation of encapsulation and oviposition since low levels of P4 were detected after ovulation in oviparous species (Koob et al. 1986; Sulikowski et al. 2004). The function of P4 in males remains unclear, with different studies showing contrasting results (Awruch 2013). However, it is probable that P4 is linked to the synthesis of $\mathrm{T}$ and other steroid hormones, which could partially be related to sexual maturation (Simpson et al. 1963; Rasmussen and Gruber, 1993). P4 has been quantified in five biological matrices using the five analytical methods described in this paper. A total of 44 papers have included P4 in their analyses, which constitutes $74.6 \%$ of the reviewed literature (Table 2).

17-hydroxyprogesterone (17-OHP). This hormone was detected throughout the complete reproductive cycle of $S$. canicula with no significant differences among the analysed months (Garnier et al. 1999). In contrast, hormones such as A4 and 17-OHP could be related to sex differentiation in male embryos of $U$. halleri (Lyons and Wynne-Edwards 2019). This progestogen has been quantified in plasma and testis of $S$. canicula and in the plasma and histotroph of $U$. halleri using RIA and LC-MS/MS, respectively (Table 2). Two papers (3.4\%) included 17-OHP in their analyses (Table 2).

Dihydroprogesterone (DHP). The study of Manire et al. (1999) demonstrated that levels of DHP significantly increased during maturation in females of $S$. tiburo but decreased before spermatogenesis in adult males along with an increase in E2 and 11-KT levels. This could be related to the synthesis of E2 and 11-KT, although this process remains unclear. The analysis of DHP was made in serum of this carcharhinid using RIA. The paper of Manire et al. (1999) constitutes $1.7 \%$ of the reviewed literature.

17-hydroxypregnenolone (17P5). The study of Gottfried and Chieffi (1967) was the only one to include 17P5 by analysing semen of S. stellaris using TLC-GC. However, this study was purely technical, focusing on hormone detection without any biological inferences. 17P5 may have receptors in the brain of elasmobranchs or may be involved in 
417

418

419

420

421

422

423

424

425

426

427

428

429

430

431

432

433

434

435

436

437

438

439

440

441

442

443

444

445

446

447

448

449

450

451

452

453

454

455

456

the synthesis of other hormones such as 17-OHP (Diotel et al 2011). However, there is no evidence to date to support the functions of 17P5 in chondrichthyans. The paper of Gottfried and Chieffi (1967) constitutes $1.7 \%$ of the reviewed literature.

Estrone (E1). This steroid was at higher levels before the gestation period of $T$. marmorata, with no detections observed during the pregnancy of this species (Di Prisco 1967). In contrast, levels of E1 and androstenedione (A4) were only detected in the histotroph of early and mid-term pregnant females of $U$. halleri (Lyons and WynneEdwards 2019). This could suggest a transfer of energy and substances for the development of these species; however, evidence about these mechanisms remains scarce. This oestrogen has been quantified in plasma and histotroph of $U$. halleri, and in the plasma of T. marmorata using LC-MS/MS and TLC-GC, respectively (Table 2), but has not been investigated in holocephans. From the reviewed literature, four papers $(6.8 \%)$ have included E1 in their analyses (Table 2).

$17 \beta$-oestradiol (E2). In chondrichthyan females, E2 has been linked to the synthesis of vitellogenin in the liver (Prisco et al. 2008), follicle development in the ovary (Koob et al. 1986; Heupel et al. 1999; Manire et al. 1999; Henningsen et al. 2008), development and functions of the oviducal gland including the storage of spermatozoa along with $\mathrm{T}$ (Koob et al. 1986; Tsang and Callard 1987; Manire et al. 1995; Tricas et al. 2000; Gelsleichter and Evans 2012; Awruch 2013), and the synthesis of protein for the capsules of oviparous species (Dodd and Goddard 1961). An increase of E2 has been related to the secretion of histotroph in the uterus of batoids (Snelson et al. 1997; Tricas et al. 2000; Lyons and Wynne-Edwards 2019), as well as to the formation of the placental connection in some viviparous sharks (Manire et al. 1995). It has been proposed that E2 is linked to the presence of relaxin and therefore involved in the preparation for parturition (Tsang and Callard 1987; Koob et al. 1984). In recent years, it was suggested that E2 and T could play an important role in sexual differentiation of batoids such as $U$. halleri (Lyons and Wynne-Edwards 2019). In males, an increase of E2 was related to spermatogenesis (Tricas et al. 2000; Sulikowski et al. 2004) and the development of gonads along with other steroids such as P4, T, and DHT (Gelsleichter et al. 2002). This oestrogen has been quantified in six biological matrices using the analytical methods described in this review except for PC/TLC-GC. From the reviewed literature, a total of 49 papers $(83.0 \%)$ have included E2 in their analyses (Table 2).

Estriol (E3). In female batoids, E3 was more abundant in immature individuals compared to mature individuals of T. marmorata (Di Prisco 1967). In a recent study, this steroid was postulated to influence sex differentiation along with E2, as it was detected in the early development of female-only litters of U. halleri (Lyons and Wynne-Edwards 2019). This oestrogen was quantified in the plasma and histotroph of U. halleri and in plasma of 
457

458

459

460

461

462

463

464

465

466

467

468

469

470

471

472

473

474

475

476

477

478

479

480

481

482

483

484

485

486

487

488

489

490

491

492

493

494

495

496

T. marmorata using LC-MS/MS and TLC-GC, respectively. From the reviewed literature, only two papers (3.4\%) have included E3 in their analyses (Table 2).

Cortisone (E). This glucocorticoid was analysed by Di Prisco et al. (1967) using plasma of T. marmorata and TLC-GC. The concentrations of E where consistently lower than F, with a decrease of these steroids from immaturity to gestation in the analysed females. In contrast, the concentrations of CORT increased. The study of Lyons and Wynne-Edwards (2019) did detect the hormone, yet it indicated concentrations below the limit of quantification in plasma, along with a lack of detections in the histotroph of $U$. halleri (Table 2). Two papers (3.4\%) using LC-MS/MS and TLC-GC included E in their reproductive analyses (Table 2 ).

Corticosterone (CORT). An increase in CORT levels was linked to sexual development and mating in males of elasmobranch species such as $N$. brevirostris, $S$. tiburo and $H$. sabinus (Rassmusen and Gruber 1993; Manire et al. 2007). In females of $S$. tiburo and $T$. marmorata, CORT was detected during mating, sperm storage and early gestation (Di Prisco 1967; Snelson et al. 1997; Manire et al. 2007). However, this pattern was not observed in females of $H$. sabinus where CORT levels were low during the entire study period (Snelson et al. 1997) but were elevated in late gestation and parturition in the study of Manire et al. (2007). Although CORT was detected in the plasma and histotroph of $U$. halleri, the concentrations were below the limit of quantification, so no biological inferences were provided (Lyons and Wynne-Edwards 2019). CORT has been quantified in blood and histotroph of several elasmobranch species using RIA, TLC-GC, or LC$\mathrm{MS} / \mathrm{MS}$, but it has not been investigated in holocephans. From the reviewed literature, five papers (8.5\%) have included CORT in their analyses (Table 2).

Cortisol $(F)$. In terms of the reproductive biology of batoids, Lyons and Wynne-Edwards (2019) observed that $\mathrm{F}$ was only present in post-ovulatory females and one early term female of $U$. halleri. In another study by Di Prisco (1967), F was detected during the whole reproductive cycle of $T$. marmorata in concentrations that were permanently higher than E. This glucocorticoid has been analysed in the plasma of T. marmorata and U. halleri using TLC-GC and LC-MS/MS, respectively, since the concentrations of these hormones were below the limit of quantification in the histotroph of $U$. halleri. Two papers $(3.4 \%)$ included $\mathrm{F}$ in their analyses (Table 2 ).

11-deoxycortisol $(S)$. Although $\mathrm{S}$ was recently detected during pregnancy in plasma and histotroph of $U$. halleri, the observed concentrations were below the limit of quantification, hence limiting our ability to draw conclusions regarding its function. The paper of Lyons and Wynne-Edwards (2019) using LC-MS/MS constitutes $1.7 \%$ of the reviewed literature. 
497

498

499

500

501

502

503

504

505

506

507

508

509

510

511

512

513

514

515

516

517

518

519

520

521

522

523

524

525

526

527

528

529

530

531

532

533

534

535

536

11-Deoxycorticosterone (DOC). In elasmobranchs, DOC was detected during different maturity stages in T. marmorata females, which could indicate its role in the synthesis of CORT and the regulation of energy and stress (Di Prisco 1967). In the case of male sharks, DOC was suggested as a protein-bound component of seminal plasma in $S$. acanthias, yet its effect on sperm motility or other influence on semen remains unknown (Simpson et al. 1964). DOC has been detected in semen of $S$. acanthias and plasma of $T$. marmorata using PC and TLC-GC, respectively (Table 2). Three papers included DOC in their analysis, which constitutes $5.1 \%$ of the reviewed literature.

11-dehydrocorticosterone (11-DHC). In chondrichthyans, 11-DHC was first detected in late term females of the round stingray $U$. halleri by Lyons and Wynne-Edwards (2019). However, the concentrations were found below the limit of quantification. It is possible that the presence of 11-DHC could be related to the conversion of this steroid to $\mathrm{F}$ or CORT by enzymes such as $11 \beta$-hydroxysteroid dehydrogenase (Pelletier 2010).

Nevertheless, the scientific research related to this topic is scarce and there is no evidence of its effects on chondrichthyan metabolism and reproduction. 11-DHC was detected using LC-MS/MS in the paper of Lyons and Wynne-Edwards (2019) which constitutes $1.7 \%$ of the reviewed literature.

General models illustrating the function of steroid hormones in male and female chondrichthyans are provided in figures 5 and 6 . These theoretical diagrams summarize the observations made to date in all the analysed species and can highly differ between taxa. In this regard, considerations for each reproductive strategy, embryonic nutrition and species should be cautiously considered since research in most of the hormones is currently insufficient. A brief summary of the effects of steroid hormones during each biological phenomenon are mentioned below. Further details are also reviewed in Maruska and Gelsleichter (2011), Gelsleichter and Evans (2012) and Awruch (2013).

Overall, male chondrichthyan steroidogenesis is initiated in the testis by the action of the luteinizing hormone $(\mathrm{LH})$ and follicle-stimulating hormone $(\mathrm{FSH})$ produced in the pituitary gland on the Sertoli and Leydig cells (Fig. 5; Callard et al. 1989). During sexual maturation, some steroids such as T, P4, 11-KT and CORT play a role as anabolic agents promoting the mitosis and further development of testis, reproductive ducts, seminal glands and claspers (Rassmusen and Gruber 1993; Manire et al. 1999; Sulikowski et al. 2005; Manire et al. 2007; Lyons and Wynne-Edwards 2019). In mature individuals, an increase of T, DHT and oestrogens such as E2 will favour spermatogenesis, while the particular function of androgens such as $\mathrm{T}$ are related to sperm motility and transportation throughout the paired reproductive ducts (Manire et al. 1997; Heupel et al. 1999; Tricas et al. 2000; Sulikowski et al. 2004, 2005). The synthesis of seminal plasma will involve the presence of DOC as a component of this substance (Simpson et

Peer) reviewing PDF | (2020:04:47925:2:0:NEW 15 Jul 2020) 
537 al. 1964), where A4 and 3 $\alpha$-diol occur during the peak of sperm reserves prior the reproductive

538

539

540

541

542

543

544

545

546

547

548

549

550

551

552

553

554

555

556

557

558

559

560

561

562

563

564

565

566

567

568

569

570

571

572

573

574

575

576

season (Garnier et al. 1999). The presence of A4 and 3 $\alpha$-diol could be a precursor for an increase in T, DHT and CORT that, in turn, will promote mating behaviours and the further copulation with females (Fig. 5; Rassmusen and Gruber 1993; Manire et al. 1995; Garnier et al. 1999; Manire et al. 2007; Mull et al. 2010).

Sexual maturation and reproductive mechanisms in mature females are influenced by the presence of LH and FSH (Fig. 6; Maruska and Gelsleichter 2011; Awruch 2013). This promotes the synthesis of $\mathrm{P} 4, \mathrm{~T}$ and $\mathrm{E} 2$ at the beginning of ovarian follicle development by its production in the granulosa and theca cells (Gelsleichter and Evans 2012). During sexual maturation and the beginning of each reproductive cycle in mature specimens, the effect of E2 on the liver favours the synthesis of vitellogenin, which is essential for oocyte development (Prisco et al. 2008). During this process, the effects of DOC and 11-DHC are linked to the synthesis of CORT and the regulation of energy and stress (Di Prisco 1967; Peletier 2010; Lyons and Wynne-Edwards 2019). In this regard, it is likely that specific steroid hormones such as $1 \alpha$-hydroxycorticosterone play an important role during all reproductive phenomena; however, their function in reproductive processes are still unclear (Iki et al. 2020). Follicle development in preparation for the beginning of the mating seasons or reproductive cycles is favoured by an increase in T, E2 and 11-KT, while the development of reproductive ducts and the oviducal gland will be related to such steroids and to the action of 11-KT (Koob et al. 1986; Heupel et al. 1999; Manire et al. 1999; Tricas et al. 2000; Henningsen et al. 2008).

After mating, the action of CORT and 11-KA4 allows sperm storage in preparation for conception and synthesis of a tertiary membrane. This structure becomes the egg case in oviparous species or a protective membrane in viviparous embryos (Hamlett 2011). A rise in P4, E1 and A4 occurs during the preparation for the passing of fertilized oocytes from the oviducal gland to the uterus (Di Prisco 1967; Koob et al. 1986; Sulikowski et al. 2004; Sheldon et al. 2018). During pregnancy, this increase in $P 4$ acts as a negative feedback for the synthesis of E2, resulting in a reduction of the vitellogenin synthesis (Tsang and Callard 1987; Tricas et al. 2000; Prisco et al. 2008; Mull et al. 2010). As previously mentioned, all these effects would change according to the species. For instance, species showing oophagy or adelphophagy could present different routes since unfertilized or fertilized oocytes are provided for the nutrition of embryos (Compagno et al., 2005; Hamlett 2011). Bloodstream levels of P4, S and 11KA4 favour the conditions for the maintenance of embryos, with the presence of CORT, E1 and A4 playing a role in the potential regulation of energy and stress (Fig. 6; Di Prisco 1967; Manire et al 1999; Sheldon et al. 2018; Lyons and Wynne-Edwards 2019).

In the case of histotrophic batoids, a rise in E2 affects the ciliated cells in the uterus for the synthesis of the histotroph (Snelson et al. 1997; Tricas et al. 2000; Lyons and Wynne-Edwards 2019), while in placental species this E2 rise is linked to the consumption of the yolk and the

Peer) reviewing PDF | (2020:04:47925:2:0:NEW 15 Jul 2020) 
577 start of a placental connection (Manire et al. 1995). Specific steroids involving androgens and 578 oestrogens such as DHT, A4, 17-OHP, E3 and E2 will play a role in the sex differentiation of 579 embryos (Tricas et al. 2000; Lyons and Wynne-Edwards 2019), with high levels of CORT 580 present during the late gestation and prior to parturition (Manire et al. 2007). In the last phases of 581 the reproductive cycle, a drop in P4 will affect the original conditions for the maintenance of 582 embryos or the start of oviposition (Koob et al. 1986; Manire et al. 1999; Sulikowski et al. 2004; 583 Mull et al. 2010). The absence of P4 allows the recommencement of E2 synthesis, which plays a 584 role in the production of relaxin for parturition (Tsang and Callard 1987; Koob et al. 1984). The 585 oviposition or the birth of the pups likely stimulates an increase in DHT levels that could act as a 586 negative feedback for the synthesis of gonadotropin-releasing hormone (Fig. 6; Tricas et al. 587 2000).

588

589

590

591

592

593

594

595

596

597

598

599

600

601

602

603

604

605

606

607

608

609

610

611

612

613

614

615 Scientific research of endocrinology in chondrichthyans has increased since the 1990s (Fig. 2d).

616 For instance, only seven articles were published between 1961 and 1990, constituting an average 
617 of 0.2 papers per year compared with the 1.8 papers published per year after 1990. This increase 618 is linked to improvements in technological and analytical methodologies, as well as the rising 619 interest for the management of these species around the world (Hammerschlag and Sulikoswki 620 2011; Cisneros-Montemayor et al. 2019).

621

622 During 1963-2020, the species of sharks with the greatest number of hormones analysed were $S$. 623 tiburo and $S$. canicula, with eight and 13 steroids, respectively. In the case of batoids, a total of 624 ten and 13 steroids were detected for T. marmorata and U. halleri, respectively (Table 4). The 625 spotted ratfish $H$. colliei is the only chimaera species in which hormones were analysed, namely 626 E2, T, and 11-KT (Barnett et al. 2009), although additional studies exist related to nuclear 627 receptors that were not considered in this review (Katsu et al. 2010; Katsu et al. 2019).

628

629 The scientific research on steroid hormones and their functions in the reproduction of chondrichthyans is mainly based on a selected number of species used as biological models.

631

632

633

634

635

636

637

638

639

640

641

642

643

644

645

646

647

648

649

650

651

652

653

654

655

656 Eighty six percent of the scientific effort has been carried out in the northern hemisphere $(n=51$ papers), including developed countries like the United States, Canada, England, Italy, and Japan (Fig. 7). This is highly related to high quality facilities, available research instrumentation and supplies, as well as financial support for the development of science, all of which are not frequently provided in developing or non-developed countries. The rest of the scientific effort $(13.8 \% ; n=8$ papers) originated from countries in the southern hemisphere such as Australia and Argentina. The latter is the only country that has explored steroid hormones in the reproduction of elasmobranchs in South America. Regrettably, research is noticeably lacking in areas with a high biodiversity of chondrichthyans such as the Caribbean and Red Sea, the Eastern Tropical Pacific, the Indo Pacific Ocean, the polar seas and nearly the entire coast of Africa (Fig. 7).

Considering the ecological richness of chondrichthyans, the analysis of additional species from different habitats could lead to a better understanding of the function of steroid hormones on the biology of sharks, rays, and chimaeras. This would in turn benefit the reproductive assessment of commercial and protected species. The existence of chondrichthyans in marine protected or nonprotected areas should motivate the development of non-lethal methods for the analysis of reproduction through hormonal profiles, which could complement the study of their biology (Hammerschlag and Sulikowski 2011; Prohaska et al. 2013a).

\section{Conclusions}

The study of steroid hormones could become increasingly relevant for the science-based management and conservation of marine wildlife such as chondrichthyans. In recent decades, there has been an increase in the protection of sharks and rays worldwide, as well as of the habitats where they feed or reproduce (Maestro et al. 2019). The holistic science-based approach to the creation of marine protected areas should include the study of the reproductive biology of 
657 the species present in these ecosystems. This would benefit from steroid analyses, along with

658

659

660

661

662

663

664

665

666

667

668

669

670

671

672

673

674

675

676

677

678

679

680

681

682

683

684

685

686

687

688

689

690

691

692

693

694

695

other methods such as ultrasounds and morphometrics for the biological monitoring of protected populations in critical habitats such as nursery areas (Anderson et al. 2018; MacKeracher et al. 2019).

Steroid hormone analyses with traditional methodologies requiring dead specimens will allow the generation of baselines, particularly for the characterization of steroid profiles throughout the reproductive cycle in the different strategies found in chondrichthyans (Prohaska et al. 2013a). Analyses of sex steroids besides E2, T and P4 are highly needed to bring to fruition all the benefits that hormonal investigation can provide to the field.

In the reviewed literature, the effects of steroid hormones on the reproductive biology of chondrichthyans were discussed according to sex and embryos nutrition. However, most of these studies analysed three sex steroids and only a few publications detected and quantified more than such number. This can be partially explained by the limitation in tissue mass, financial support, available antibodies, and methods for the simultaneous analysis of a larger quantity of hormones using the same biopsy. Systematic research using captive model species under controlled environments can clarify the function of E2, T and P4 on specific biological phenomena, while the combination of methods could provide relevant insights of the role of other steroid hormones during such reproductive processes.

Although the obtained information is highly valuable for present and future comparisons, the consideration of bias in terms of cross reactivity should be considered (Nozu et al. 2015, 2017; Mylniczenko et al. 2018). Sharks, rays, and chimaeras depose urea and other metabolic waste such as trimethylamine oxide in the blood (Compagno et al. 2005; Nelson et al. 2016). This constitutes an adaptation for energetics in terms of homeostasis, as blood from chondrichthyans has a higher salinity than water (Compagno et al. 2005). In this regard, the presence of metabolites interacting with antibodies during immunoassays should be analysed in future studies, since most of the research used blood with no consideration of metabolic waste and pollutants that could be present in the bloodstream of these taxa.

The use of sensitive physical-based separation techniques that can simultaneously detect multiple steroid hormones and their metabolites in tissues other than blood, has proved to be useful in other groups of vulnerable species such as cetaceans (Boggs et al. 2017; Hayden et al. 2017) and in the round stingray $U$. halleri (Lyons and Wynne-Edwards 2019). Although it is a new approach for the study of endocrinology in marine wildlife, LC-MS/MS has shown high-quality results (limit of detection, precision, and recovery) using small tissue mass obtained from minimally invasive sample collection such as skin (Boggs et al. 2017; Hayden et al 2017). The validation of this method in different matrices and species of chondrichthyans, along with 
696 complementary techniques, can create a new alternative for the study of commercial and 697 protected species (Hammerschalg and Kulikoswki 2011; Wudy et al. 2018).

698

699

700

701

702

703

704

705

706

707

708

709

710

711

712

713

714

715

716

717

718

719

720

721

722

723

724

725

726

727

728

729

730

731

732

733

734

The study of hormone panels from small samples obtained by non-lethal collection using validated physical-based separation methodologies could greatly benefit the scientific monitoring and protection of vulnerable species. One of the main concerns should be focused on the successful extraction, detection, and quantification of steroid hormones from small biopsies of tissues (Boggs et al. 2017; Hayden et al 2017). When it is achieved, these non-lethal techniques will be an important tool for research, and therefore the conservation of protected and cosmopolitan taxa such as the white shark, whale shark and mantas that are commercially used by ecotourism in several localities around the world (Hammerschlag and Sulikowski 2011; Cisneros-Montemayor et al. 2019).

\section{Acknowledgements}

The authors thank E. Georgina Molina and Leonardo Trejo for their support in the design of the figures.

\section{References}

Anderson B, Belcher C, Slack J, Gelsleichter J (2018) Evaluation of the use of portable ultrasonography to determine pregnancy status and fecundity in bonnethead shark Sphyrna tiburo. J Fish Biol 93(6):1163-1170 https://doi.org/10.1111/jfb.13831.

Awruch CA, Frusher SD, Pankhurst NW, Stevens JD (2008b) Non-lethal assessment of reproductive characteristics for management and conservation of sharks. Mar Ecol Prog Ser 355:277-285 https://doi.org/10.3354/meps07227

Awruch CA, Pankhurst NW, Frusher SD, Stevens JD (2008a) Endocrine and morphological correlates of reproduction in the draughtboard shark Cephaloscyllium laticeps (Elasmobranchii: Scyliorhinidae). J Exp Zool Part A 309(4):184-197 https://doi.org/10.1002/jez.445

Awruch CA, Pankhurst NW, Frusher SD, Stevens JD (2009) Reproductive seasonality and embryo development in the draughtboard shark Cephaloscyllium laticeps. Mar Freshwater Res 60(12):1265-1272 https://doi.org/10.1071/MF09030

Awruch CA (2013) Reproductive endocrinology in chondrichthyans: the present and the future. Gen Comp Endocr 192: 60-70 https://doi.org/10.1016/j.ygcen.2013.05.021

Awruch CA, Jones SM, Asorey MG, Barnett A (2014) Non-lethal assessment of the reproductive status of broadnose sevengill sharks (Notorynchus cepedianus) to determine the significance of 
735 habitat use in coastal areas. Conserv Physiol 2(1):cou013

736 https://doi.org/10.1093/conphys/cou013

737

738

Barnett LA, Earley RL, Ebert DA, Cailliet GM (2009) Maturity, fecundity, and reproductive

739 cycle of the spotted ratfish, Hydrolagus colliei. Mar Biol 156(3):301-316

740 https://doi.org/10.1007/s00227-008-1084-y

741

742 Bhawani SA, Sulaiman O, Hashim R, Ibrahim MN (2010) Thin-layer chromatographic analysis

743 of steroids: A review. Trop J Pharm Res 9(3) https://doi.org/10.4314/tjpr.v9i3.56293

744

745

746

Boggs AS, Schock TB, Schwacke LH, Galligan TM, Morey JS, McFee WE, Kucklick JR (2017)

747

748 Rapid and reliable steroid hormone profiling in Tursiops truncatus blubber using liquid chromatography tandem mass spectrometry (LC-MS/MS). Anal Bioanal Chem 409(21): 50195029.

749

750

751

752

753

754

755

756

757

758

759

760

761

762

763

764

765

766

767

768

769

770

771

Bubley WJ, Sulikowski JA, Koester DM, Tsang PC (2013) Using a multi-parameter approach to reassess maturity of spiny dogfish, Squalus acanthias, following increased fishing pressure in the Western North Atlantic. Fish Res 147:202-212 https://doi.org/10.1016/j.fishres.2013.06.004

Castro JI, Sato K, Bodine AB (2016) A novel mode of embryonic nutrition in the tiger shark, Galeocerdo cuvier. Mar Bio Res 12(2):200-205 https://doi.org/10.1080/17451000.2015.1099677

Callard G, Mak P, DuBois W, Cuevas ME (1989) Regulation of spermatogenesis: the shark testis model. J Ex Zool 252(S2): 23-34.

Cisneros-Montemayor AM, Becerril-García EE, Berdeja-Zavala O, Ayala-Bocos A (2019) Shark ecotourism in Mexico: Scientific research, conservation, and contribution to a Blue Economy. Conservation of Mexican Shark, Academic Press. https://doi. Org/10.1016/bs. Amb, 3.

Compagno L, Dando M, Fowler S (2005) Sharks of the World. Harper Collins, London.

Diamandis EP (1988) Immunoassays with time-resolved fluorescence spectroscopy: principles and applications. Clin Biochem 21(2):139-150 https://doi.org/10.1016/S0009-9120(88)80104-8

Di Prisco CL, Vellano C, Chieffi G (1967) Steroid hormones in the plasma of the elasmobranch Torpedo marmorata at various stages of the sexual cycle. Gen Comp Endocr 8(2):325-331 https://doi.org/10.1016/0016-6480(67)90080-9

772 
773 Diotel N, Do-Rego JL, Anglade I, Vaillant C, Pellegrini E, Vaudry H, Kah O (2011) The brain of

774 teleost fish, a source, and a target of sexual steroids. Front Neurosci 5: 137

775 https://doi.org/10.3389/fnins.2011.00137

776

777 Dodd JM, Goddard CK (1961) Some effects of oestradiol benzoate on the reproductive ducts of

778 the female dogfish Scyliorhinus caniculus. Proc Zool Soc Lond 137(3):325-331

779 https://doi.org/10.1111/j.1469-7998.1961.tb05907.x

780

781

782

Elisio M, Awruch CA, Massa AM, Macchi GJ, Somoza GM (2019) Effects of temperature on

783 the reproductive physiology of female elasmobranchs: The case of the narrownose smoothhound shark (Mustelus schmitti). Gen Comp Endocr 284:113242

784 https://doi.org/10.1016/j.ygcen.2019.113242

785

786

Fasano S, d'Antonio M, Pierantoni R, Chieffi G (1992) Plasma and follicular tissue steroid levels 787 in the elasmobranch fish, Torpedo marmorata. Gen Comp Endocr 85(2):327-333

788

789

790

791 https://doi.org/10.1016/0016-6480(92)90017-e

Froese, R. and D. Pauly. Editors (2019) FishBase. World Wide Web electronic publication. www.fishbase.org, version (12/2019).

792

793

Fujinami Y, Semba Y (2020) Non-lethal assessment of reproductive stage for female blue sharks 794

795

796

797

Prionace glauca using sex steroid hormones. J Fish Biol https://doi.org/10.1111/jfb.14312

Garnier DH, Sourdaine P, Jégou B (1999) Seasonal variations in sex steroids and male sexual characteristics in Scyliorhinus canicula. Gen Comp Endocr 116(2):281-290

798 https://doi.org/10.1006/gcen.1999.7369

799

800 Gelsleichter J, Rasmussen LEL, Manire CA, Tyminski J, Chang B, Lombardi-Carlson L (2002)

801 Serum steroid concentrations and development of reproductive organs during puberty in male

802 bonnethead sharks, Sphyrna tiburo. Fish Physiol Biochem 26(4):389-401

803 https://doi.org/10.1023/B:FISH.0000009292.70958.65

804

805 Gelsleichter J, Walsh CJ, Szabo NJ, Rasmussen LE (2006) Organochlorine concentrations,

806 reproductive physiology, and immune function in unique populations of freshwater Atlantic

807 stingrays (Dasyatis sabina) from Florida's St. Johns River. Chemosphere 63(9):1506-1522

808 https://doi.org/10.1016/j.chemosphere.2005.09.011

809

810 Gelsleichter J, Evans AN (2012) Hormonal regulation of elasmobranch physiology. In: Carrier

811 JC, Musick JA, Heithaus MR (eds) Biology of Sharks and Their Relatives, $2^{\text {nd }}$ edn. CRC Press, 812 pp 313-348. 
813

814 Goldsmith SJ (1975) Radioimmunoassay: Review of basic principles. Semin Nucl Med 5(2):125-

815152 https://doi.org/10.1016/S0001-2998(75)80028-6

816

817 Gottfried H, Chieffi G (1967) The seminal steroids of the dogfish Scylliorhinus stellaris. J

818 Endocrinol 37(1):99-100 https://doi.org/10.1677/joe.0.0370099

819

820

821

822

823

824

825

826

827

828

829

830

831

832

833

834

835

836

837

838

839

840

841

842

843

844

845

846

847

848

849

850

851

852

Guida L, Awruch C, Walker TI, Reina RD (2017) Prenatal stress from trawl capture affects mothers and neonates: a case study using the southern fiddler ray (Trygonorrhina dumerilii). Sci Rep 7:46300 https://doi.org/10.1038/srep46300.

Hamlett WC (2011) Reproductive biology and phylogeny of Chondrichthyes: sharks, batoids, and chimaeras, vol 3. CRC Press.

Hammerschlag N, Sulikowski J (2011) Killing for conservation: the need for alternatives to lethal sampling of apex predatory sharks. Endanger Species Res 14(2):135-140

https://doi.org/10.3354/esr00354

Hayden M, Bhawal R, Escobedo J, Harmon C, O'Hara T, Klein D, San-Francisco S, Zabet-Moghaddam M, Godard-Codding CA (2017) Nano-LC-MS/MS analysis of steroids from gray whale blubber. Rapid Comm Mass Spectrom 31: 1088-1094 DOI: 10.1002/rcm.7884.

Henningsen AD, Murru FL, Rasmussen LEL, Whitaker BR, Violetta GC (2008) Serum levels of reproductive steroid hormones in captive sand tiger sharks, Carcharias taurus (Rafinesque), and comments on their relation to sexual conflicts. Fish Physiol Biochem 34(4):437

https://doi.org/10.1007/s10695-008-9202-9

Heupel MR, Whittier JM, Bennett MB (1999) Plasma steroid hormone profiles and reproductive biology of the epaulette shark, Hemiscyllium ocellatum. J Exp Zool 284(5):586-594

https://doi.org/10.1002/(SICI)1097-010X(19991001)284:5<586::AID-JEZ14>3.0.CO;2-B

Hoffmayer ER, Sulikowski JA, Hendon JM, Parsons GR (2010) Plasma steroid concentrations of adult male Atlantic sharpnose sharks, Rhizoprionodon terraenovae, in the northern Gulf of Mexico, with notes on potential long term shifts in reproductive timing. Environ Biol Fishes 88(1):1-7 https://doi.org/10.1007/s10641-010-9603-3

Huveneers C, Apps K, Becerril-García EE, Bruce B, Butcher PA, Carlisle AB, Chapple TK, Christiansen HM, Cliff G, Curtis TH, Daly-Engel TS, Dewar H, Dicken ML, Domeier ML, Duffy CAJ, Ford R, Francis MP, French GCA, Galván-Magaña F, García-Rodríguez E, Gennari E, Graham B, Hayden B, Hoyos-Padilla EM, Hussey NE, Jewell OJD, Jorgensen SJ, Kock AA, 
853 Lowe CG, Lyons K, Meyer L, Oelofse G, Oñate-González EC, Oosthuizen E, O’Sullivan JB, 854 Ramm K, Skomal G, Sloan S, Smale MJ, Sosa-Nishizaki O, Sperone E, Tamburin E, Towner 855 AV, Wcisel MA, Weng KC, Werry JM (2018) Future research directions on the "Elusive" White 856 Shark. Front Mar Sci 5:455 https://doi.org/10.3389/fmars.2018.00455

857

858

Idler DR (2012) Steroids in nonmammalian vertebrates. Academic Press, New York.

859

860

Iki A, Anderson WG, Deck CA, Ogihara MH, Ikeba K, Kataoka H, Hyodo S (2020)

861 Measurement of $1 \alpha$ hydroxycorticosterone in the Japanese banded houndshark, Triakis scyllium, 862 following exposure to a series of stressors. Gen Comp Endocr 292: 113440.

863 Katsu Y, Kohno S, Narita H, Urushitani H, Yamane K, Hara A, Clauss TM, Walsh MT, 864 Miyagawa S, Guillette Jr LJ, Iguchi T. (2010). Cloning and functional characterization of 865 Chondrichthyes, cloudy catshark, Scyliorhinus torazame and whale shark, Rhincodon typus 866 estrogen receptors. Gen Comp Endocr 168(3): 496-504.

867

868

Katsu Y, Kohno S, Oka K, Lin X, Otake S, Pillai NE, Takagi W, Hyodo S, Venkatesh B, Baker

869 ME (2019) Transcriptional activation of elephant shark mineralocorticoid receptor by

870 corticosteroids, progesterone, and spironolactone. Sci Signal 12(584):eaar2668

871 https://doi.org/10.1126/scisignal.aar2668.

872

873 Kneebone J, Ferguson DE, Sulikowski JA, Tsang PC (2007) Endocrinological investigation into 874 the reproductive cycles of two sympatric skate species, Malacoraja senta and Amblyraja radiata, 875 in the western Gulf of Maine. In: Ebert DA, Sulikowski JA (eds) Biology of Skates. Dordrecht, 876 Springer, pp 151-159.

877

878

879

Koob TJ, Tsang P, Callard IP (1986) Plasma estradiol, testosterone, and progesterone levels

880 during the ovulatory cycle of the skate (Raja erinacea). Biol Reprod 35(2):267-275

881

882 https://doi.org/10.1095/biolreprod35.2.267

883

884

885

886

Koob TJ, Laffan JJ, Callard IP (1984) Effects of Retaxin and Insulin on Reproductive Tract Size and Early Fetal Loss in Squalus acanthias. Biol Reprod 31(2): 231-238.

887

888

889

Lyons K, Wynne-Edwards KE (2019) Steroid concentrations in maternal serum and uterine histotroph in round stingrays (Urobatis halleri). Gen Comp Endocr 274:8-16

https://doi.org/10.1016/j.ygcen.2018.12.009

890

MacKeracher T, Diedrich A, Simpfendorfer CA (2019) Sharks, rays and marine protected areas:

891 A critical evaluation of current perspectives. Fish Fish 20(2):255-267

892 https://doi.org/10.1111/faf.12337 
893 Maestro M, Pérez-Cayeiro ML, Chica-Ruiz JA, Reyes H (2019) Marine protected areas in the $89421^{\text {st }}$ century: Current situation and trends. Ocean Coast Manage 171:28-36

895 https://doi.org/10.1016/j.ocecoaman.2019.01.008

896

897

898

899

900

901

902

903

904

905

906

907

908

909

910

911

912

913

914

915

916

917

918

919

920

921

922

923

924

925

926

927

928

929

930

931

932

Manire CA, Rasmussen LEL, Hess DL, Hueter RE (1995) Serum steroid hormones and the reproductive cycle of the female bonnethead shark, Sphyrna tiburo. Gen Comp Endocr 97(3):366-376 https://doi.org/10.1006/gcen.1995.1036

Manire CA, Rasmussen LEL (1997) Serum concentrations of steroid hormones in the mature male bonnethead shark, Sphyrna tiburo. Gen Comp Endocr 107(3):414-420

https://doi.org/10.1006/gcen.1997.6937

Manire CA, Rasmussen LEL, Gross TS (1999) Serum steroid hormones including 11-ketotestosterone, 11-ketoandrostenedione, and dihydroprogesterone in juvenile and adult bonnethead sharks, Sphyrna tiburo. J Exp Zool 284(5):595-603 https://doi.org/10.1002/(sici)1097-010x(19991001)284:5<595::aid-jez15>3.0.co;2-6

Manire CA, Rasmussen LEL, Gelsleichter J, Hess DL (2004) Maternal serum and yolk hormone concentrations in the placental viviparous bonnethead shark, Sphyrna tiburo. Gen Comp Endocr 136(2):241-247 https://doi.org/10.1016/j.ygcen.2003.12.018

Manire CA, Rasmussen LEL, Maruska KP, Tricas TC (2007) Sex, seasonal, and stress-related variations in elasmobranch corticosterone concentrations. Comp Biochem Phys A 148(4):926935 https://doi.org/10.1016/j.cbpa.2007.09.017

Maruska KP, Gelsleichter J (2011) Hormones and reproduction in chondrichthyan fishes. In: Norris D, Lopez KH (eds) Hormones and Reproduction of Vertebrates. Academic Press, pp 209237

Matsumoto R, Matsumoto Y, Ueda K, Suzuki M, Asahina K, Sato K (2019) Sexual maturation in a male whale shark (Rhincodon typus) based on observations made over 20 years of captivity. Fish Bull 117 https://doi.org/10.2108/zs150040

Melmed S, Polonsky KS, Larsen PR, Kronenberg HM (2015) Williams Textbook of Endocrinology. Elsevier Health Sciences https://doi.org/10.1016/C2013-0-15980-6

Mull CG, Lowe CG, Young KA (2008) Photoperiod and water temperature regulation of seasonal reproduction in male round stingrays (Urobatis halleri). Comp Biochem Phys A 151(4):717-725 https://doi.org/10.1016/j.cbpa.2008.08.029

Peer] reviewing PDF | (2020:04:47925:2:0:NEW 15 Jul 2020) 
933 Mull CG, Lowe CG, Young KA (2010) Seasonal reproduction of female round stingrays 934 (Urobatis halleri): steroid hormone profiles and assessing reproductive state. Gen Comp 935 Endocr 166(2):379-387 https://doi.org/10.1016/j.ygcen.2009.12.009.

936

937

938

939

940

941

942

943

944

945

946

947

948

949

950

951

952

953

954

955

956

957

958

959

960

961

962

963

964

965

966

967

968

969

970

971

972

Mylniczenko ND, Sumigama S, Wyffels JT, Wheaton CJ, Guttridge TL, DiRocco S, Penfold LM (2019) Ultrasonographic and hormonal characterization of reproductive health and disease in wild, semiwild, and aquarium-housed southern stingrays (Hypanus americanus). Am J Vet Res 80(10): 931-942. https://doi.org/10.2460/ajvr.80.10.931

Nau MR, O'Brien JK, Schmitt TL, Nollens HH, Robeck TR (2018) Diagnostic assessment of reproductive status in white-spotted bamboo sharks (Chiloscyllium plagiosum). Anim Reprod Sci 197:48-57 https://doi.org/10.1016/j.anireprosci.2018.08.005

Nelson JS, Grande TC, Wilson MV (2016) Fishes of the World. John Wiley \& Sons, New Jersey.

Nozu R, Murakumo K, Matsumoto R, Nakamura M, Ueda K, Sato K (2015) Gonadal morphology, histology, and endocrinological characteristics of immature female whale sharks, Rhincodon typus. Zool Sci 32(5):455-458 https://doi.org/10.2108/zs150040.

Nozu R, Murakumo K, Matsumoto R, Matsumoto Y, Yano N, Nakamura M, Yanagisawa M, Ueda K, Sato K (2017) High-resolution monitoring from birth to sexual maturity of a male reef manta ray, Mobula alfredi, held in captivity for 7 years: changes in external morphology, behavior, and steroid hormones levels. BMC Zool 2(1):14 https://doi.org/10.1186/s40850-0170023-0

Nozu R, Murakumo K, Yano N, Furuyama R, Matsumoto R, Yanagisawa M, Sato K (2018) Changes in sex steroid hormone levels reflect the reproductive status of captive female zebra sharks (Stegostoma fasciatum). Gen Comp Endocr 265:174-179

https://doi.org/10.1016/j.ygcen.2018.03.006.

Pelletier G (2010) Steroidogenic enzymes in the brain: morphological aspects. In: Dierssen M (ed) Progress in Brain Research, vol 181. Elsevier, pp 193-207 https://doi.org/10.1016/S00796123(08)81011-4

Prisco M, Valiante S, Maddalena Di Fiore M, Raucci F, Del Giudice G, Romano M, Laforgia V, Limatola E, Andreuccetti (2008) Effect of $17 \beta$-estradiol and progesterone on vitellogenesis in the spotted ray Torpedo marmorata Risso 1810 (Elasmobranchii: Torpediniformes): studies on females and on estrogen-treated males. Gen Comp Endocr (2):125-132

https://doi.org/10.1016/j.ygcen.2008.04.011

Peer] reviewing PDF | (2020:04:47925:2:0:NEW 15 Jul 2020) 
973

974 Prohaska BK, Tsang PC, Driggers III WB, Hoffmayer ER, Sulikowski JA (2013a) Development

975 of a nonlethal and minimally invasive protocol to study elasmobranch reproduction. Mar Coast

976 Fish 5(1):181-188 https://doi.org/10.1080/19425120.2013.788590

977

978 Prohaska BK, Tsang PC, Driggers III WB, Hoffmayer ER, Wheeler CR, Brown AC, Sulikowski

979 JA (2013b) Assessing reproductive status in elasmobranch fishes using steroid hormones

980 extracted from skeletal muscle tissue. Conserv Physiol 1(1): $\cot 028$

981 https://doi.org/10.1093/conphys/cot028

982

983

984

985

986

987

988

989

990

991

992

993

994

995

996

997

998

999

1000

1001

1002

1003

1004

1005

1006

1007

1008

1009

1010

1011

Prohaska BK, Tsang PCW, Driggers III WB, Hoffmayer ER, Wheeler CR, Sulikowski JA (2018) Effects of delayed phlebotomy on plasma steroid hormone concentrations in two elasmobranch species. J Appl Ichthyol 34(4):861-866 https://doi.org/10.1111/jai.13700

Rasmussen LEL, Murru FL (1992) Long-term studies of serum concentrations of reproductively related steroid hormones in individual captive carcharhinids. Mar Freshwater Res 43(1):273-281 https://doi.org/10.1071/MF9920273

Rasmussen LE, Gruber SH (1993) Serum concentrations of reproductively-related circulating steroid hormones in the free-ranging lemon shark, Negaprion brevirostris. In: Wourms JP, Demski LS (eds) The Reproduction and Development of Sharks, Skates, Rays and Ratfishes. Dordrecht, Springer, pp 167-174. https://doi.org/10.1007/978-94-017-3450-9

Rasmussen LEL, Hess DL, Luer CA (1999) Alterations in serum steroid concentrations in the clearnose skate, Raja eglanteria: correlations with season and reproductive status. J Exp Zool 284(5):575-585 https://doi.org/10.1002/(sici)1097-010x(19991001)284:5<575::aidjez13>3.3.co;2-9

Sheldon JD, Allender MC, George RH, Bulman F, Abney K (2018) Reproductive hormone patterns in male and female cownose rays (Rhinoptera bonasus) in an aquarium setting and correlation to ultrasonographic staging. J Zoo Wildlife Med 49(3):638-647

https://doi.org/10.1638/2017-0247.1

Simpson TH, Wright RS, Gottfried H (1963) Steroids in the semen of dogfish (Squalus acanthias). J Endocrinol 26(4):489-498 https://doi.org/ 10.1677/joe.0.0260489

Simpson TH, Wright RS, Hunt SV (1964) Steroid biosynthesis in the testis of dogfish (Squalus acanthias). J Endocrinol 31(1):29-38 https://doi.org/10.1677/joe.0.0310011 
1012 Snelson Jr FF, Rasmussen LEL, Johnson MR, Hess DL (1997) Serum concentrations of steroid 1013 hormones during reproduction in the Atlantic stingray, Dasyatis sabina. Gen Comp Endocr 1014 108(1):67-79 https://doi.org/10.1006/gcen.1997.6949

1015

1016

1017

1018

1019

1020

1021

1022

1023

1024

1025

1026

1027

1028

1029

1030

1031

1032

1033

1034

1035

1036

1037

1038

1039

1040

1041

1042

1043

1044

1045

1046

1047

1048

1049

Sueiro MC, Awruch CA, Irigoyen AJ, Argemi F, Palacios MG (2019) Seasonality of immunological and health-state parameters of wild broadnose sevengill shark, Notorynchus cepedianus. Physiol Biochem Zool 92(1):24-36 https://doi.org/10.1086/700573.

Sulikowski JA, Driggers WB, Ingram GW, Kneebone J, Ferguson DE, Tsang PC (2007)

Profiling plasma steroid hormones: a non-lethal approach for the study of skate reproductive biology and its potential use in conservation management. In: Ebert DA, Sulikowski JA (eds) Biology of Skates. Dordrecht, Springer, pp 179-186 https://doi.org/10.1007/978-1-40209703-4_13

Sulikowski JA, Kneebone J, Elzey S, Jurek J, Howell WH, Tsang PCW (2006) Using the composite variables of reproductive morphology, histology and steroid hormones to determine age and size at sexual maturity for the thorny skate Amblyraja radiata in the western Gulf of Maine. J Fish Biol 69(5):1449-1465 https://doi.org/10.1111/j.1095-8649.2006.01207.x

Sulikowski JA, Tsang PCW, Howell WH (2004) An annual cycle of steroid hormone concentrations and gonad development in the winter skate, Leucoraja ocellata, from the western Gulf of Maine. Mar Biol 144(5):845-853 https://doi.org/10.1007/s00227-003-1264-8

Sulikowski JA, Tsang PC, Howell WH (2005) Age and size at sexual maturity for the winter skate, Leucoraja ocellata, in the western Gulf of Maine based on morphological, histological and steroid hormone analyses. Environ Biol Fishes 72(4):429-441 https://doi.org/10.1007/s10641004-2866-9

Sulikowski JA, Wheeler CR, Gallagher AJ, Prohaska BK, Langan JA, Hammerschlag N (2016) Seasonal and life-stage variation in the reproductive ecology of a marine apex predator, the tiger shark Galeocerdo cuvier, at a protected female-dominated site. Aquat Biol 24(3):175-184 https://doi.org/10.3354/ab00648

Sulikowski JA, Williams LJ, Domeier ML (2012) The use of a nonlethal technique to assess the reproductive biology of the white shark, Carcharodon carcharias. In: Domeier (ed) Global Perspectives on the Biology and Life History of the white shark. CRC Press, Boca Raton, pp $467-476$

Peer) reviewing PDF | (2020:04:47925:2:0:NEW 15 Jul 2020) 
1050 Sumpter JP, Dodd JM (1979) The annual reproductive cycle of the female lesser spotted dogfish, 1051 Scyliorhinus canicula L., and its endocrine control. J Fish Biol 15(6):687-695

1052 https://doi.org/10.1111/j.1095-8649.1979.tb03678.x

1053

1054

Tosti L, Danovaro R, Dell'Anno A, Olivotto I, Bompadre S, Clò S, Carnevali O (2006)

1055 Vitellogenesis in the deep-sea shark Centroscymnus coelolepis. Chem Ecol 22(4):335-345

1056 https://doi.org/10.1080/02757540600812016

1057

1058

Tricas TC, Maruska KP, Rasmussen LEL (2000) Annual cycles of steroid hormone production, 1059 gonad development, and reproductive behavior in the Atlantic stingray. Gen Comp Endocr

1060

1061

1062 118(2):209-225 https://doi.org/10.1006/gcen.2000.7466

1063

Tsang PC, Callard IP (1987) Morphological and endocrine correlates of the reproductive cycle of the aplacental viviparous dogfish, Squalus acanthias. Gen Comp Endocr 66(2):182-189

1064 https://doi.org/10.1016/0016-6480(87)90266-8

1065

1066

1067

1068

1069

Vashist SK, Luong JH (2018) Handbook of immunoassay technologies: approaches, performances, and applications. Academic Press

1070

Waltrick D, Jones SM, Simpfendorfer CA, Awruch CA (2014) Endocrine control of embryonic 1071 diapause in the Australian sharpnose shark Rhizoprionodon taylori. PLoS One 9(7): e101234 https://doi.org/10.1371/journal.pone.0101234

1072

1073

Weigmann S (2016) Annotated checklist of the living sharks, batoids and chimaeras

1074 (Chondrichthyes) of the world, with a focus on biogeographical diversity. J Fish Biol 88(3), 837-

1075 1037 https://doi.org/10.1111/jfb. 12874

1076

1077

1078

1079

1080

1081

1082

Williams LJ, Campbell MD, Tsang PC, Sulikowski JA (2013) Using estradiol and progesterone concentrations to assess individual variability in the reproductive cyclicity of captive female little skates, Leucoraja erinacea, from the western Gulf of Maine. Fish Physiol Biochem 39(5):10891099 https://doi.org/10.1007/s10695-012-9766-2

1083

Wudy SA, Schuler G, Sánchez-Guijo A, Hartmann MF (2018) The art of measuring steroids:

1084 principles and practice of current hormonal steroid analysis. J Steroid Biochem 179:88-103 https://doi.org/10.1016/j.jsbmb.2017.09.003

1085

1086

Wyffels JT, George R, Adams L, Adams C, Clauss T, Newton A, Hyatt MW, Yach C, Penfold 1087 LM (2019) Testosterone and semen seasonality for the sand tiger shark Carcharias taurus. Biol 1088 Reprod 102(4):876-887 https://doi.org/10.1093/biolre/ioz221

1089 
Figure 1

Number of chondrichthyans according to embryonic nutrition (a) and conservation status (b; IUCN, 2020) that have been studied in terms of steroid hormones during 1963-2020 ( $n=34$ species)

a

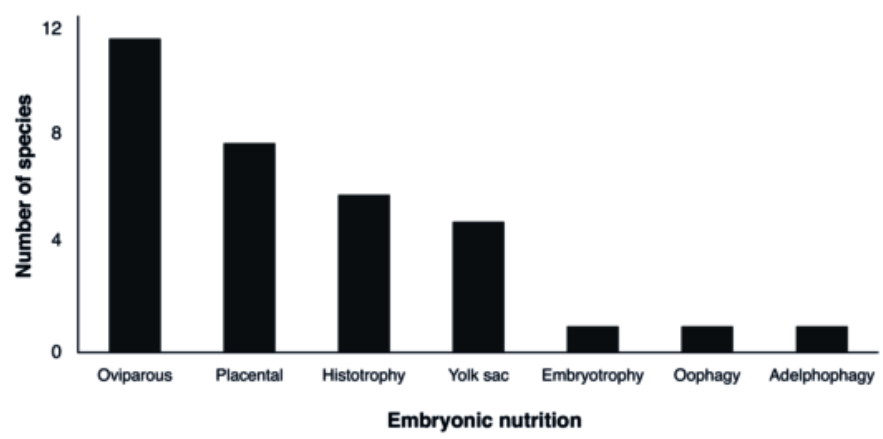

b

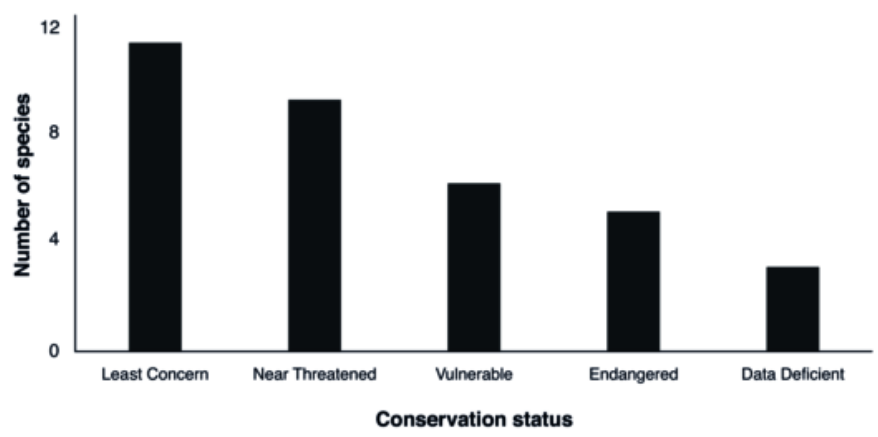




\section{Figure 2}

Scientific literature related to the analysis of steroid hormones in chondrichthyans during 1963-2020 ( $n=59$ papers).

(A) methodology used. (B) biological matrix. (C) hormones per paper. (D) number of papers according to decade. Abbreviations: Radioimmunoassay (RIA); Enzyme immunoassay or enzyme-linked immunosorbent assay (EIA/ELISA); Time-resolved fluorescent immunoassay (TRFIA); Paper chromatography or thin layer chromatography followed by gas chromatography (PC/TLC-GC); Liquid chromatography coupled with triple quadrupole tandem mass spectrometry and electrospray ionization with multiple reaction monitoring (LC-MS/MS); Plasma (P); Histotroph (H): Muscle (M); Gonad (G); Serum (S); Semen (Se); Yolk (Y).

a

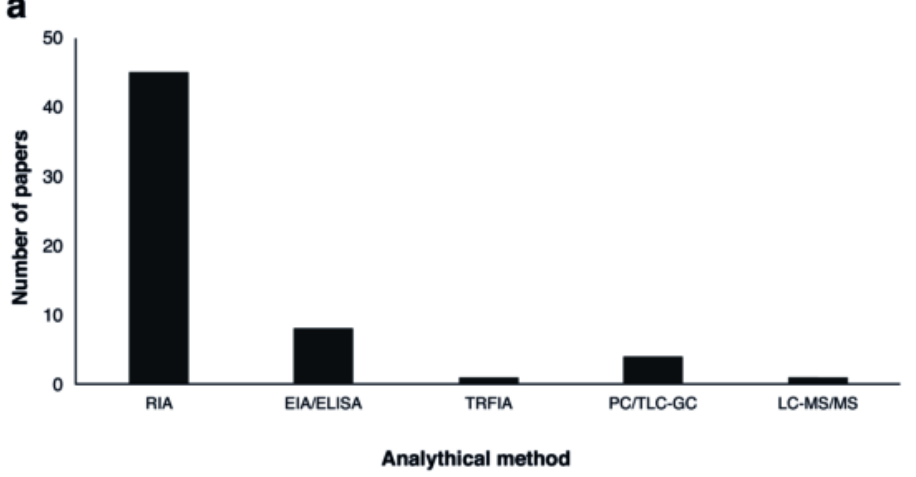

C

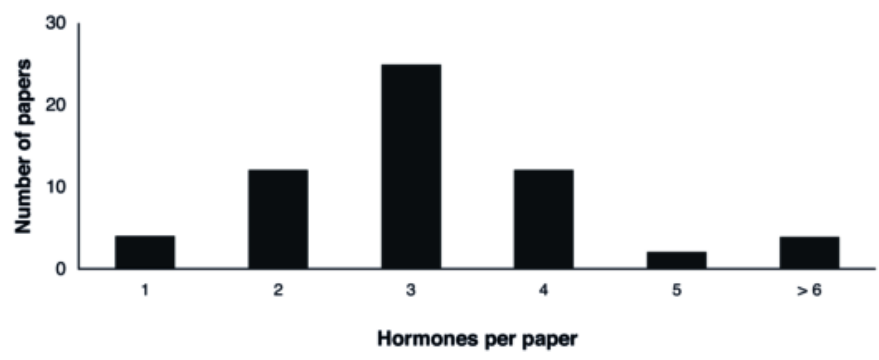

b

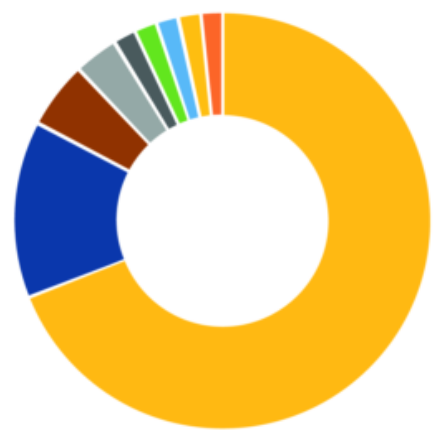

12 $P(n=41)$

- $P, H(n=1)$

- $P, M(n=2)$

- P, G $(n=1)$

- $P, M, G(n=1)$

n, $P, H(n=1)$

- $S(n=8)$

- $S e(n=3)$

- $S, Y(n=1)$

d

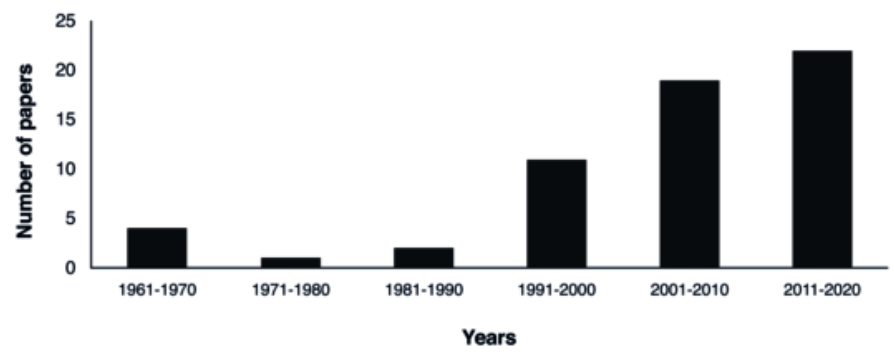




\section{Figure 3}

Number of steroids per paper according to the method used for the study of chondrichthyan reproduction during 1963-2020.

Mean, $25 \%$ and $75 \%$ percentiles, outliers ( $)$, minimum and maximum ( $n=59$ papers).

Abbreviations: Radioimmunoassay (RIA); Enzyme immunoassay or enzyme-linked

immunosorbent assay (EIA/ELISA); Time-resolved fluorescent immunoassay (TRFIA); Paper

chromatography or thin layer chromatography followed by gas chromatography (PC/TLC-GC);

Liquid chromatography coupled with triple quadrupole tandem mass spectrometry and electrospray ionization with multiple reaction monitoring (LC-MS/MS).

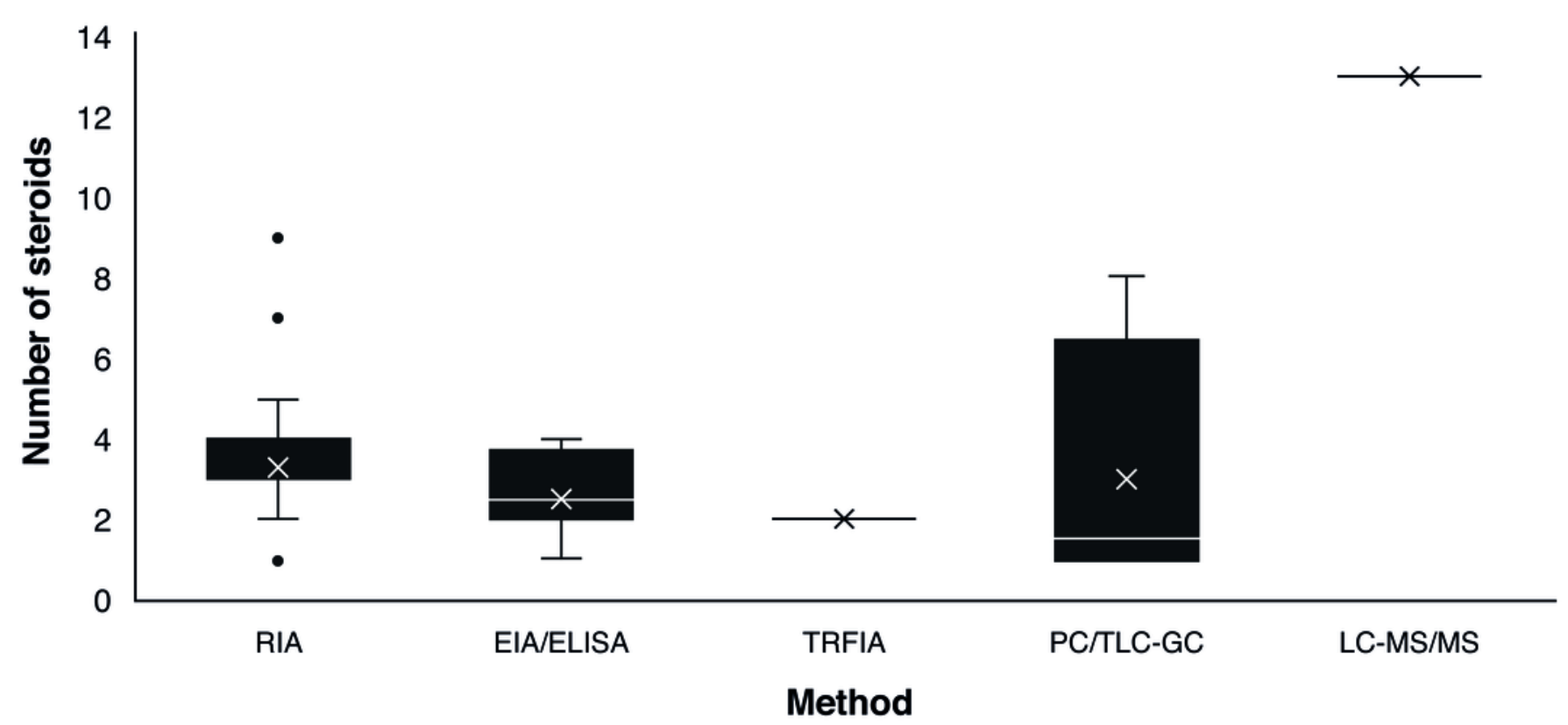


Figure 4

Number of analysed steroids according to their type $(n=19)$.

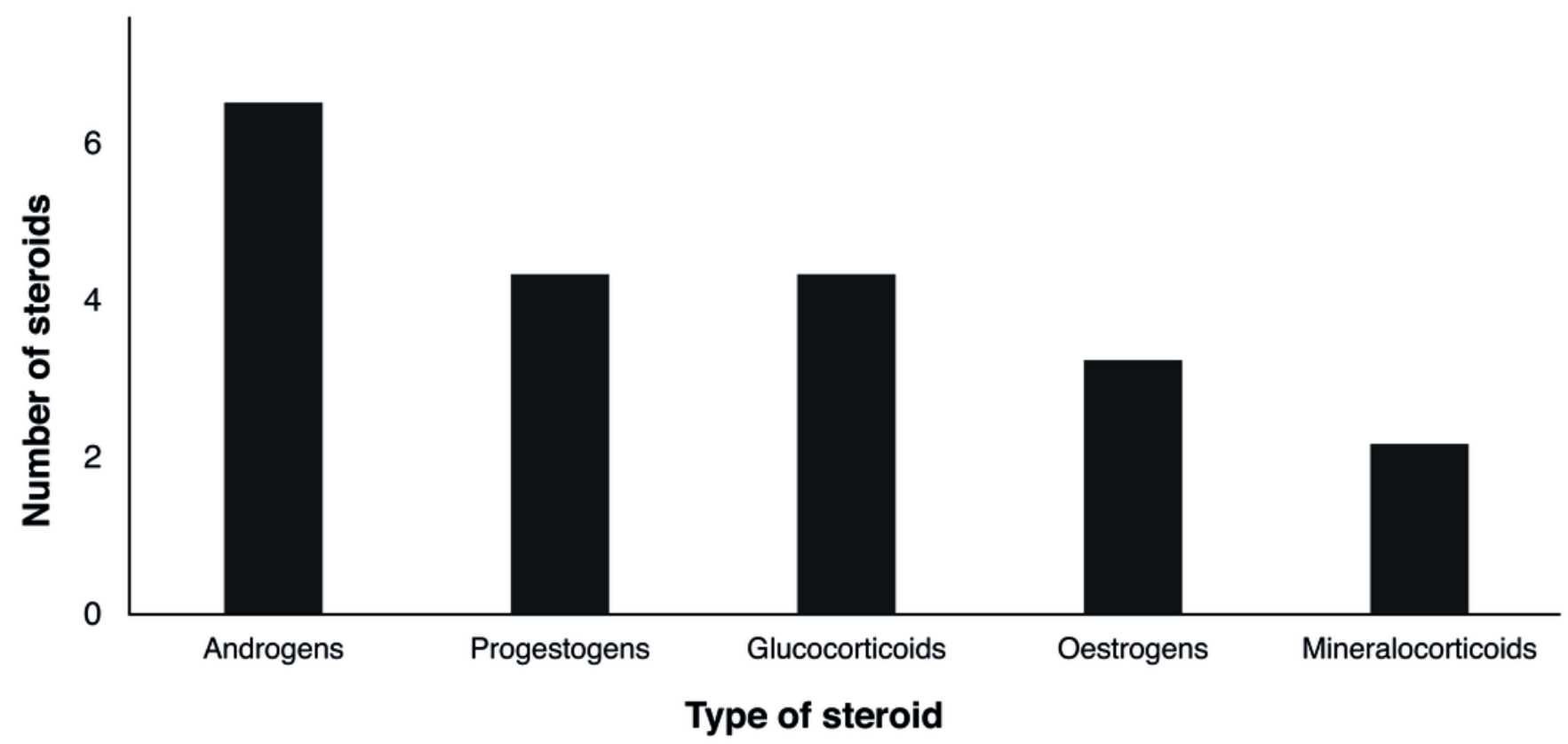




\section{Figure 5}

General model of the endocrinology of male chondrichthyans in terms of steroid hormones and reproductive biology.

Abbreviations: Gonadotropin releasing hormone $(\mathrm{GnRH})$; luteinizing hormone (LH); follicle stimulating hormone (FSH); 17 -oestradiol (E2); testosterone (T); progesterone (P4); $5 \alpha$ dihydrotestosterone (DHT); 11-ketotestosterone (11-KT); corticosterone (CORT);

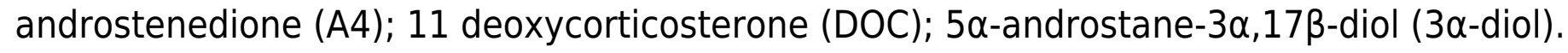




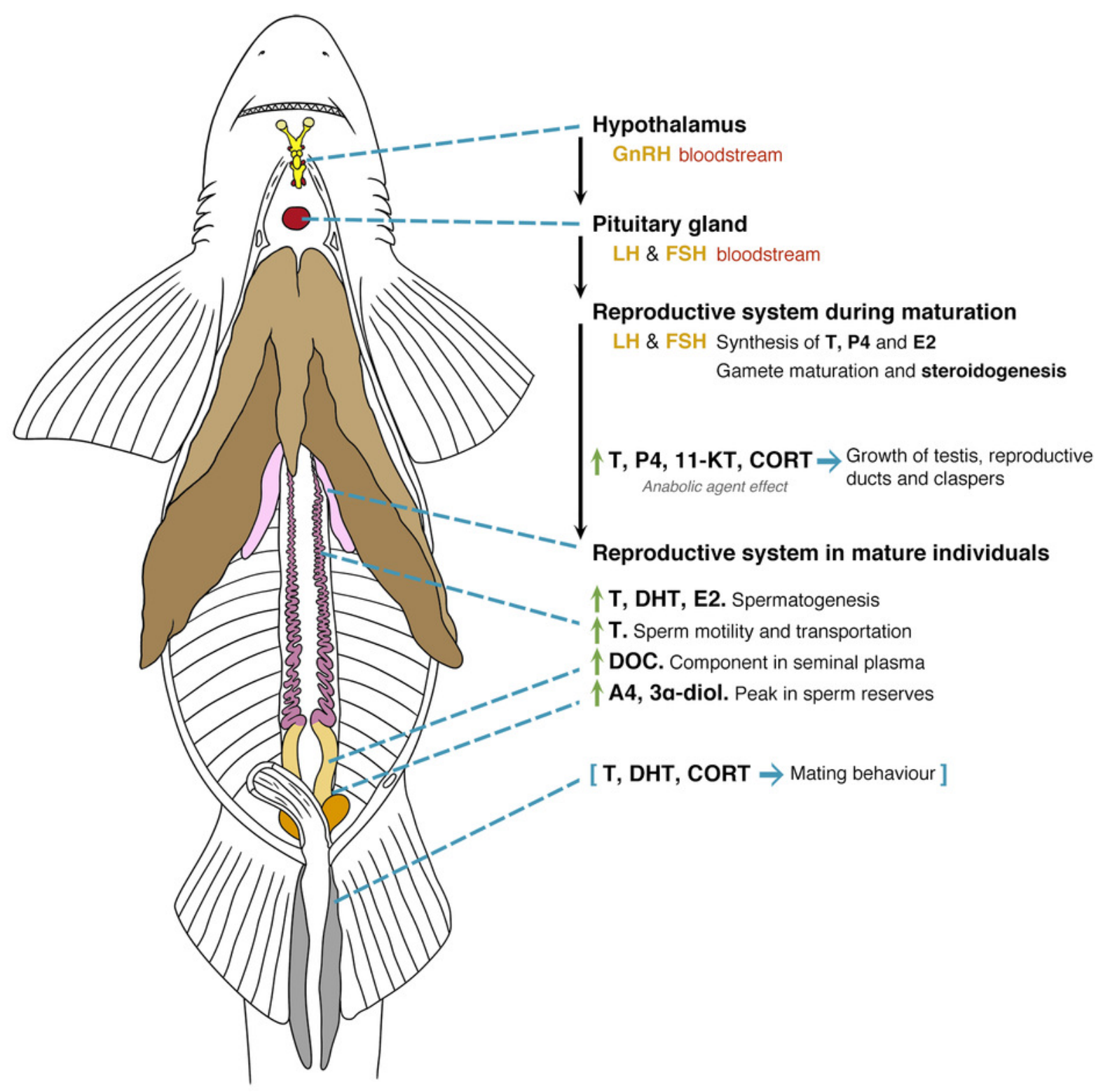




\section{Figure 6}

General model of the endocrinology of female chondrichthyans in terms of steroid hormones and reproductive biology.

Abbreviations: Gonadotropin releasing hormone $(\mathrm{GnRH})$; luteinizing hormone (LH); follicle stimulating hormone (FSH); 17 -oestradiol (E2); testosterone (T); progesterone (P4); $5 \alpha$ dihydrotestosterone (DHT); 11-ketotestosterone (11-KT); corticosterone (CORT); androstenedione (A4); 17-hydroxyprogesterone (17-OHP); estrone (E1); estriol (E3); cortisone (E); cortisol (F); 11-deoxycortisol (S); dihydroprogesterone (DHP); 11 deoxycorticosterone

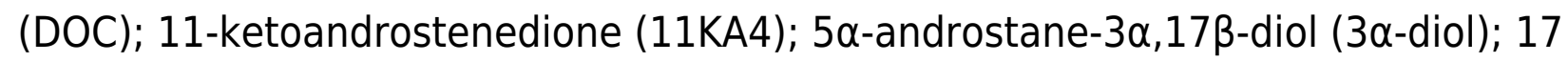
hydroxypregnenolone (17P5); 11-dehydrocorticosterone (11-DHC). 


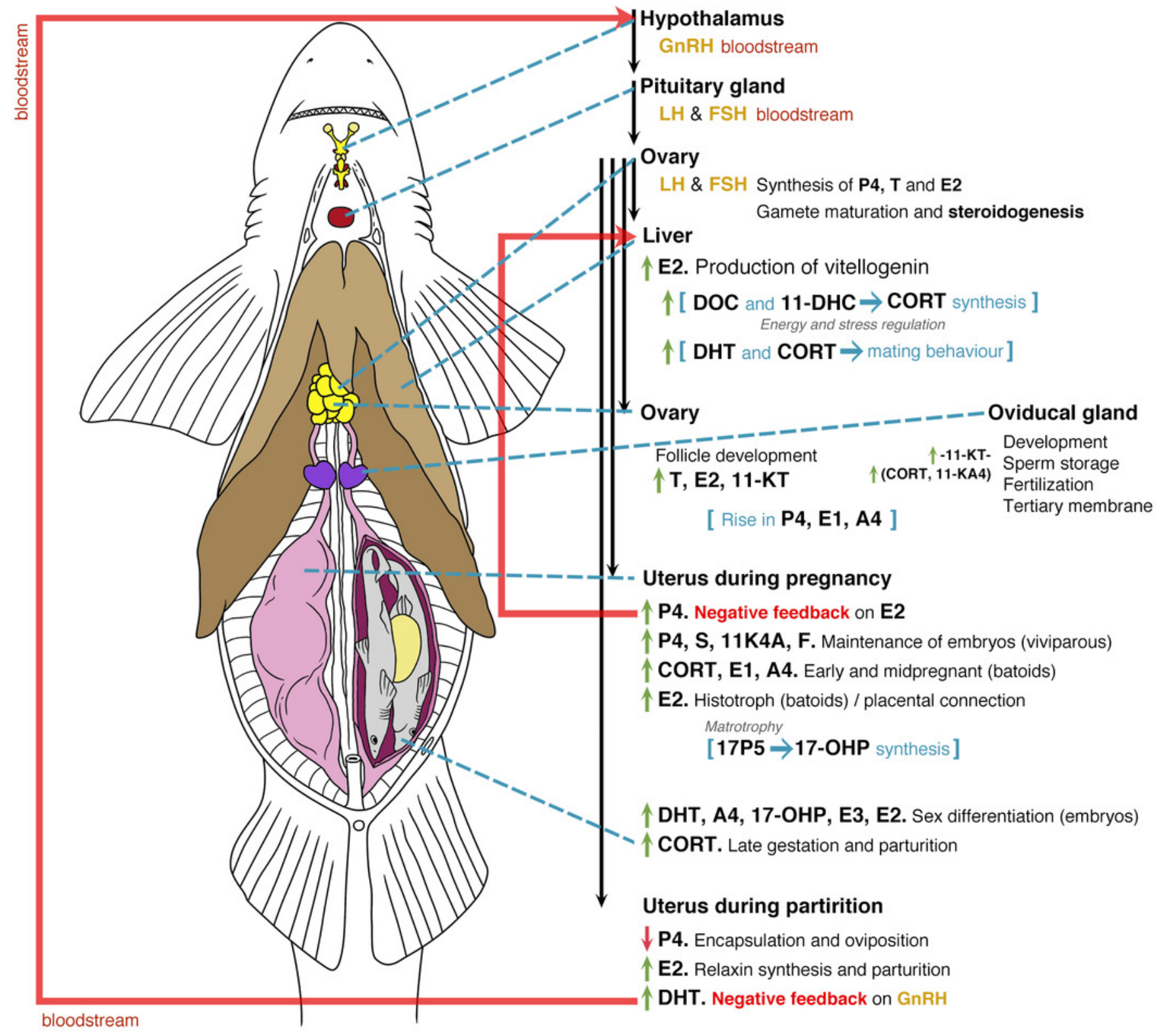


Figure 7

Kernel's density heat map indicating the regions with scientific effort related to steroid hormones and reproduction in chondrichthyans during 1963-2020 ( $n=59$ papers).

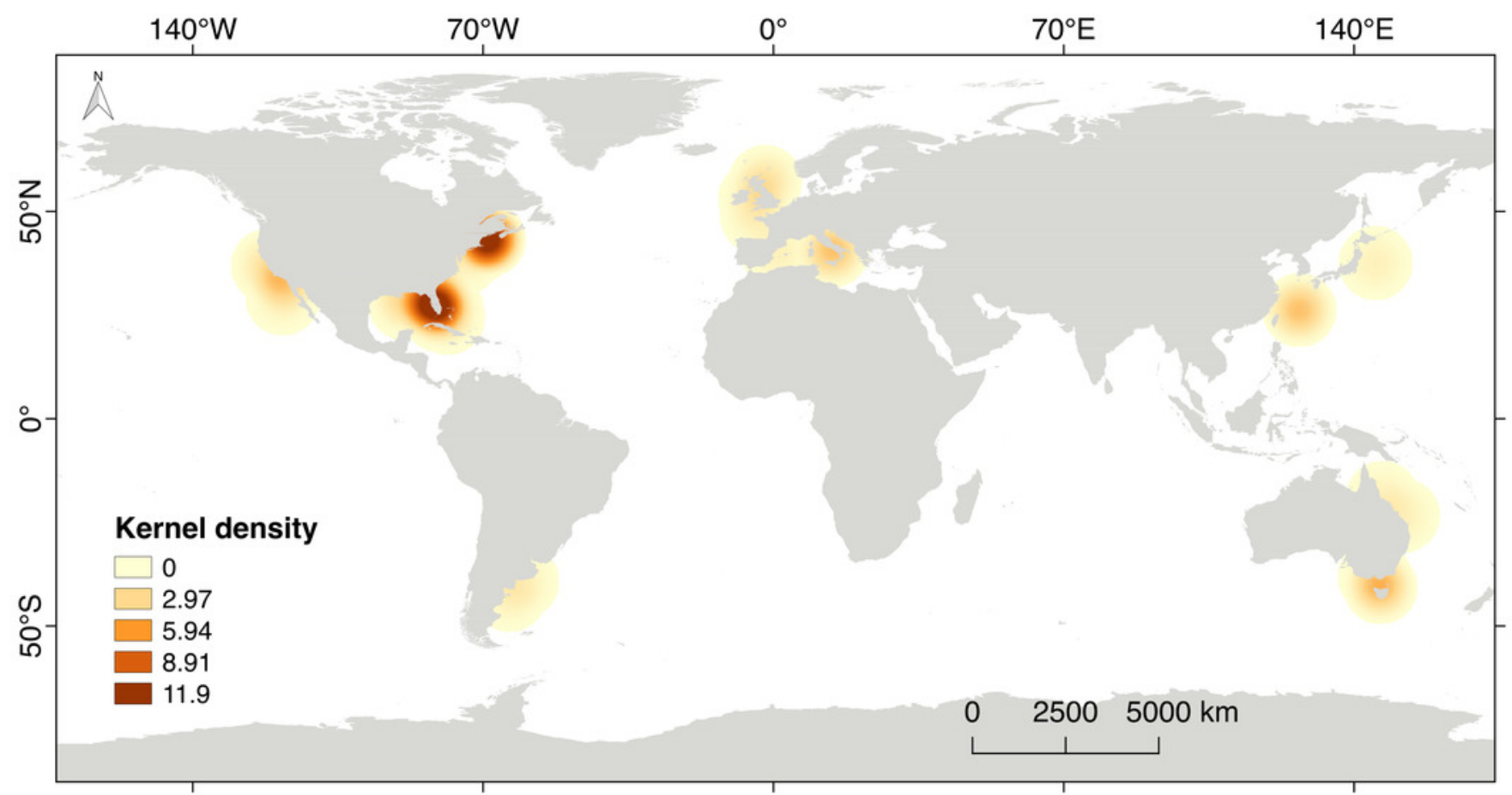




\section{Table 1 (on next page)}

Chondrichthyan species subject to steroid hormones and reproduction analyses during 1963-2020.

Data include reproductive strategy and the conservation status according to IUCN (2020). Abbreviations: Data Deficient (DD); Least Concern (LC); Near Threatened (NT); Vulnerable (VU); Endangered (EN). 
Table 1: Chondrichthyan species subject to steroid hormones and reproduction analyses during 1963-2020.

2 Data include reproductive strategy and the conservation status according to IUCN (2020). Abbreviations: Data Deficient (DD); Least Concern (LC);

3 Near Threatened (NT); Vulnerable (VU); Endangered (EN).

\begin{tabular}{|c|c|c|c|c|c|}
\hline Species & Common name & Order & Family & Reproductive strategy & IUCN status \\
\hline$\overline{\text { Hydrolagus colliei }}$ & Spotted ratfish & Chimaeriformes & Chimaeridae & Oviparous & LC \\
\hline Notorynchus cepedianus & Broadnose sevengill & Hexanchiformes & Hexanchidae & Yolk-sac viviparous & DD \\
\hline Centroscymnus coelolepis & Portuguese dogfish & Squaliformes & Somniosidae & Yolk-sac viviparous & NT \\
\hline Squalus acanthias & Spiny dogfish shark & Squaliformes & Squalidae & Yolk-sac viviparous & VU \\
\hline Chiloscyllium plagiosum & White-spotted bamboo shark & Orectolobiformes & Hemiscylliidae & Oviparous & NT \\
\hline Hemiscyllium ocellatum & Eupaulette shark & Orectolobiformes & Hemiscylliidae & Oviparous & LC \\
\hline Rhincodon typus & Whale shark & Orectolobiformes & Rhincodontidae & Yolk-sac viviparous & $\mathrm{EN}$ \\
\hline Stegostoma fasciatum & Zebra shark & Orectolobiformes & Stegostomatidae & Oviparous & $\mathrm{EN}$ \\
\hline Carcharodon carcharias & White shark & Lamniformes & Lamnidae & Oophagy & VU \\
\hline Carcharias taurus & Sand tiger shark & Lamniformes & Lamnidae & Adelphophagy & VU \\
\hline Carcharhinus leucas & Bull shark & Carcharhiniformes & Carcharhinidae & Placental viviparous & NT \\
\hline Carcharhinus plumbeus & Sandbar shark & Carcharhiniformes & Carcharhinidae & Placental viviparous & VU \\
\hline Galeocerdo cuvier & Tiger shark & Carcharhiniformes & Carcharhinidae & Embryotrophy & NT \\
\hline Negaprion brevirostris & Lemon shark & Carcharhiniformes & Carcharhinidae & Placental viviparous & NT \\
\hline Prionace glauca & Blue shark & Carcharhiniformes & Carcharhinidae & Placental viviparous & NT \\
\hline Rhizoprionodon taylori & Australian sharpnose shark & Carcharhiniformes & Carcharhinidae & Placental viviparous & LC \\
\hline Rhizoprionodon terranovae & Atlantic Sharpnose shark & Carcharhiniformes & Carcharhinidae & Placental viviparous & $\mathrm{LC}$ \\
\hline Cephalloscyllium laticeps & Draughtboard shark & Carcharhiniformes & Scyliorhinidae & Oviparous & LC \\
\hline Scyliorhinus canicula & Small spotted catshark & Carcharhiniformes & Scyliorhinidae & Oviparous & $\mathrm{LC}$ \\
\hline Scyliorhinus stellaris & Nursehound & Carcharhiniformes & Scyliorhinidae & Oviparous & NT \\
\hline Sphyrna tiburo & Bonnethead shark & Carcharhiniformes & Sphyrnidae & Placental viviparous & LC \\
\hline Mustelus schmitti & Narrownose smooth hound & Carcharhiniformes & Triakidae & Placental viviparous & EN \\
\hline Trygonorrhina dumerilii & Southern fiddler ray & Rhinopristiformes & Trygonorrhinidae & Yolk-sac viviparous & $\mathrm{LC}$ \\
\hline Amblyraja radiata & Thorny skate & Rajiformes & Rajidae & Oviparous & VU \\
\hline Leucoraja erinacea & Little skate & Rajiformes & Rajidae & Oviparous & NT \\
\hline Leucoraja ocellata & Winter skate & Rajiformes & Rajidae & Oviparous & $\mathrm{EN}$ \\
\hline Malacoraja senta & Smooth skate & Rajiformes & Rajidae & Oviparous & $\mathrm{EN}$ \\
\hline Raja eglanteria & Clearnose skate & Rajiformes & Rajidae & Oviparous & $\mathrm{LC}$ \\
\hline Torpedo marmorata & Spotted ray & Torpediniformes & Torpedinidae & Histotrophic viviparous & DD \\
\hline
\end{tabular}




\begin{tabular}{lclll} 
Hypanus sabinus & Freshwater Atlantic stingray & Myliobatiformes & Dasyatidae & Histotrophic viviparous \\
Hypanus americanus & Southern stingray & Myliobatiformes & Dasyatidae & Histotrophic viviparous \\
Mobula alfredi & Reef manta ray & Myliobatiformes & Myliobatidae & Histotrophic viviparous \\
Rhinoptera bonasus & Cownose rays & Myliobatiformes & Myliobatidae & Histotrophic viviparous \\
Urobatis halleri & Round stingray & Myliobatiformes & Urotrygonidae & Histotrophic viviparous \\
\hline
\end{tabular}




\section{Table 2 (on next page)}

Scientific research regarding steroid hormones in chondrichthyan reproduction during 1963-2020.

Data includes methods (RIA: radioimmunoassay; EIA/ELISA: enzyme immunoassay or enzyme-linked immunosorbent assay; TRFIA: time resolved fluorescent assay; PC: paper chromatography; TLC-GC: thin-layer chromatography followed by gas chromatography; LCMS/MS: Liquid chromatography tandem mass spectrometry); tissues (S: semen; P: plasma; Se: serum; G: gonad; Y: yolk; M: muscle; H: histotroph); analysed hormones (E2: 17ßoestradiol; T: testosterone; P4: progesterone; DHT: $5 \alpha$-dihydrotestosterone; 11-KT: 11ketotestosterone; CORT: corticosterone; A4: androstenedione; 17-OHP: 17hydroxyprogesterone; E1: estrone; E3: estriol; E: cortisone; F: cortisol; S: 11-deoxycortisol; DHP: dihydroprogesterone; DOC: 11 deoxycorticosterone; 11KA4: 11-ketoandrostenedione; $3 \alpha$-diol: $5 \alpha$-androstane-3 $\alpha, 17 \beta$-diol; 17P5: 17 hydroxypregnenolone; 11-DHC: 11dehydrocorticosterone); original volume per sample $(\mathrm{g}, \mathrm{mL})$; volume for analysis $(\mu \mathrm{L})$; recovery or extraction efficiency (\%); and lethality of the method. Dash (-) used when the information was not specified. 


\section{Table 2: Scientific research regarding steroid hormones in chondrichthyan reproduction during 1963-2020.}

Data includes methods (RIA: radioimmunoassay; EIA/ELISA: enzyme immunoassay or enzyme-linked immunosorbent assay; TRFIA: time resolved fluorescent assay; PC: paper chromatography; TLC-GC: thin-layer chromatography followed by gas chromatography; LC-MS/MS: Liquid chromatography tandem mass spectrometry); tissues (S: semen; P: plasma; Se: serum; G: gonad; Y: yolk; M: muscle; H: histotroph); analysed hormones (E2: 17ß-oestradiol; T: testosterone; P4: progesterone; DHT: 5a-dihydrotestosterone; 11-KT: 11-ketotestosterone; CORT: corticosterone; A4: androstenedione; 17-OHP: 17-hydroxyprogesterone; E1: estrone; E3: estriol; E: cortisone; F: cortisol; S: 11-deoxycortisol; DHP: dihydroprogesterone; DOC: 11 deoxycorticosterone; 11KA4: 11-ketoandrostenedione; 3a-diol: 5a-androstane-3a,17ß-diol; 17P5: 17 hydroxypregnenolone; 11-DHC: 11-dehydrocorticosterone); original volume per sample $(\mathrm{g}, \mathrm{mL})$; volume for analysis $(\mu \mathrm{L})$; recovery or extraction efficiency (\%); and lethality of the method. Dash (-) used when the information was not specified.

\begin{tabular}{|c|c|c|c|c|c|c|c|c|}
\hline Species & Method & Tissue & Analysed hormones & $\begin{array}{c}\text { Volume per } \\
\text { sample }\end{array}$ & $\begin{array}{c}\text { Volume for } \\
\text { analysis }\end{array}$ & $\begin{array}{l}\text { Extraction } \\
\text { efficiency }\end{array}$ & Lethality & References \\
\hline Hydrolagus colliei & RIA & $\mathrm{M}, \mathrm{P}$ & $\mathrm{E} 2, \mathrm{~T}, 11-\mathrm{KT}$ & - & $0.5 \mathrm{~g}, 500 \mu \mathrm{L}$ & $69-111$ & Lethal & Barnett et al., 2008 \\
\hline Notorhynchus cepedianus & RIA & $\mathrm{P}$ & $\mathrm{E} 2, \mathrm{~T}, \mathrm{P} 4$ & $3 \mathrm{~mL}$ & $200 \mu \mathrm{L}$ & $83-92$ & Lethal & Awruch et al., 2014 \\
\hline N. cepedianus & RIA & $\mathrm{P}$ & $\mathrm{E} 2, \mathrm{~T}, \mathrm{P} 4$ & $5 \mathrm{~mL}$ & $200 \mu \mathrm{L}$ & - & Lethal & Suiero et al., 2019 \\
\hline Centroscymnus coelolepis & RIA & $\mathrm{P}$ & $\mathrm{E} 2, \mathrm{~T}, \mathrm{P} 4$ & $1-1.5 \mathrm{~mL}$ & $25 \mu \mathrm{L}$ & - & Lethal & Tosti et al., 2006 \\
\hline Squalus acanthias & RIA & $\mathrm{P}$ & $\mathrm{E} 2, \mathrm{~T}, \mathrm{P} 4$ & $0.5-1 \mathrm{~mL}$ & $50 \mu \mathrm{L}$ & $80-92$ & Lethal & Tsang and Callard et al., 1987 \\
\hline S. acanthias & RIA & $\mathrm{P}$ & $\mathrm{E} 2, \mathrm{~T}, \mathrm{P} 4$ & $5 \mathrm{~mL}$ & - & $67-82$ & Lethal & Bubely et al., 2013 \\
\hline$S$ acanthias & RIA & $\mathrm{M}, \mathrm{G}, \mathrm{P}$ & $\mathrm{E} 2, \mathrm{~T}, \mathrm{P} 4$ & $5 \mathrm{~g}, 8 \mathrm{~mL}$ & $2 \mathrm{~g}, 100 \mu \mathrm{L}$ & $20-85$ & Lethal & Prohaska et al., 2013a \\
\hline S. acanthias & RIA & $\mathrm{M}, \mathrm{P}$ & $\mathrm{E} 2, \mathrm{~T}, \mathrm{P} 4$ & $5 \mathrm{~g}, 8 \mathrm{~mL}$ & $2 \mathrm{~g}, 100 \mu \mathrm{L}$ & $74-91$ & Lethal & Prohaska et al., 2013b \\
\hline S. acanthias & RIA & $\mathrm{P}$ & $\mathrm{E} 2, \mathrm{~T}, \mathrm{P} 4$ & $5 \mathrm{~mL}$ & $400 \mu \mathrm{L}$ & $71-90$ & Lethal & Prohaska et al., 2018 \\
\hline Chiloscyllium plagiosum & RIA & $\mathrm{P}$ & $\mathrm{E} 2, \mathrm{~T}, \mathrm{P} 4$ & $2.5 \mathrm{~mL}$ & $200 \mu \mathrm{L}$ & $17-93$ & Non-Lethal & Nau et al., 2018 \\
\hline Hemiscyllium ocellatum & RIA & $P$ & $\mathrm{E} 2, \mathrm{P} 4, \mathrm{~T}$ & $1 \mathrm{~mL}$ & - & - & Lethal & Heupel et al., 1999 \\
\hline Carcharodon carcharias & RIA & $\mathrm{P}$ & $\mathrm{E} 2, \mathrm{~T}, \mathrm{P} 4$ & $10 \mathrm{~mL}$ & $400 \mu \mathrm{L}$ & - & Non-Lethal & Sulikowski et al., 2012 \\
\hline Carcharias taurus & RIA & $\mathrm{Se}$ & E2, T, P4, DHT & $10 \mathrm{~mL}$ & - & $66-81$ & Non-Lethal & Henningsen et al., 2008 \\
\hline Carcharhinus leucas & RIA & $\mathrm{Se}$ & E2, T, P4, DHT & $5 \mathrm{~mL}$ & - & - & Non-Lethal & Rasmussen and Muru, 1992 \\
\hline Carcharhinus plumbeus & RIA & $\mathrm{Se}$ & E2, T, P4, DHT & $5 \mathrm{~mL}$ & - & - & Non-Lethal & Rasmussen and Muru, 1992 \\
\hline Galeocerdo cuvier & RIA & $\mathrm{P}$ & $\mathrm{E} 2, \mathrm{~T}, \mathrm{P} 4$ & $20 \mathrm{~mL}$ & $500 \mu \mathrm{L}$ & $59-84$ & Non-Lethal & Sulikowski et al., 2016 \\
\hline Negaprion brevirostris & RIA & $\mathrm{Se}$ & E2, T, P4, DHT & $5 \mathrm{~mL}$ & - & - & Non-Lethal & Rasmussen and Muru, 1992 \\
\hline N. brevirostris & RIA & $\mathrm{Se}$ & E2, T, P4, DHT, CORT & $5-20 \mathrm{~mL}$ & - & - & Non-Lethal & Rasmussen and Gruber, 1993 \\
\hline Rhizoprionodon taylori & RIA & $\mathrm{P}$ & $\mathrm{E} 2, \mathrm{~T}, \mathrm{P} 4$ & $3 \mathrm{~mL}$ & $100 \mu \mathrm{L}$ & $86-90$ & Lethal & Waltrick et al., 2014 \\
\hline Rhizoprionodon terranovae & RIA & $\mathrm{M}, \mathrm{G}, \mathrm{P}$ & $\mathrm{E} 2, \mathrm{~T}, \mathrm{P} 4$ & $5 \mathrm{~g}, 8 \mathrm{~mL}$ & $2 \mathrm{~g}, 100 \mu \mathrm{L}$ & $39-87$ & Lethal & Prohaska et al., 2013a \\
\hline R. terranovae & RIA & $\mathrm{P}, \mathrm{M}$ & $\mathrm{E} 2, \mathrm{~T}, \mathrm{P} 4$ & $5 \mathrm{~g}, 8 \mathrm{~mL}$ & $2 \mathrm{~g}, 100 \mu \mathrm{L}$ & $74-91$ & Lethal & Prohaska et al., 2013b \\
\hline R. terranovae & RIA & $\mathrm{E} 2, \mathrm{~T}, \mathrm{P} 4 \mathrm{P}$ & & $5 \mathrm{~mL}$ & $400 \mu \mathrm{L}$ & $60-91$ & Lethal & Prohaska et al., 2018 \\
\hline Cephalloscyllium laticeps & RIA & $\mathrm{P}$ & $\mathrm{E} 2, \mathrm{~T}, \mathrm{P} 4,11-\mathrm{KT}$ & $3 \mathrm{~mL}$ & $200 \mu \mathrm{L}$ & $74-88$ & Lethal & Awruch et al., 2008a \\
\hline C. laticeps & RIA & $\mathrm{P}$ & $\mathrm{E} 2, \mathrm{~T}, \mathrm{P} 4$ & $3 \mathrm{~mL}$ & $200 \mu \mathrm{L}$ & $74-86$ & Lethal & Awruch et al., 2008b \\
\hline
\end{tabular}




\begin{tabular}{|c|c|c|c|c|c|c|c|c|}
\hline C. laticeps & RIA & $\mathrm{P}$ & $\mathrm{E} 2, \mathrm{~T}, \mathrm{P} 4$ & $3 \mathrm{~mL}$ & $200 \mu \mathrm{L}$ & $74-86$ & Lethal & Awruch et al., 2009 \\
\hline Scyliorhinus canicula & RIA & $\mathrm{P}$ & $\mathrm{E} 2, \mathrm{~T}$ & $2 \mathrm{~mL}$ & $50 \mu \mathrm{L}$ & - & Lethal & Sumpter and Dodd, 1979 \\
\hline S. canicula & RIA & $\mathrm{P}, \mathrm{G}$ & $\begin{array}{l}\text { E2, T, P4, DHT, 11-KT, } \\
\text { E1, A4, } \\
\text { 17-OHP, 3 } \alpha \text {-diol }\end{array}$ & - & - & $35-85$ & Lethal & Garnier et al., 1999 \\
\hline Sphyrna tiburo & RIA & $\mathrm{Se}$ & E2, T, P4, DHT & - & $500 \mu \mathrm{L}$ & $70-88$ & Lethal & Manire et al., 1995 \\
\hline S. tiburo & RIA & $\mathrm{Se}$ & E2, T, P4, DHT & - & $500 \mu \mathrm{L}$ & - & Lethal & Manire et al., 1997 \\
\hline S. tiburo & RIA & $\mathrm{Se}$ & $\begin{array}{l}\text { E2, T, P4, DHT, 11-KT, } \\
\text { DHP, 11KA4 }\end{array}$ & - & $50 \mu \mathrm{L}$ & $84-87$ & Lethal & Manire et al., 1999 \\
\hline S. tiburo & RIA & $\mathrm{Se}$ & $\mathrm{E} 2, \mathrm{~T}, \mathrm{P} 4, \mathrm{DHT}$ & - & $500 \mu \mathrm{L}$ & - & Lethal & Geslecihter et al., 2002 \\
\hline S. tiburo & RIA & $\mathrm{Se}, \mathrm{Y}$ & $\mathrm{E} 2, \mathrm{~T}, \mathrm{P} 4$ & - & $500 \mu \mathrm{L}$ & $62-68$ & Lethal & Manire et al., 2004 \\
\hline S. tiburo & RIA & $\mathrm{P}$ & CORT & - & $25-75 \mu \mathrm{L}$ & 89 & Lethal & Manire et al., 2007 \\
\hline Mustelus schmitti & RIA & $\mathrm{P}$ & $\mathrm{E} 2, \mathrm{~T}, \mathrm{P} 4$ & - & $500 \mu \mathrm{L}$ & 95 & Lethal & Elisio et al., 2019 \\
\hline Trygonorrhina dumerilii & RIA & $\mathrm{P}$ & $\mathrm{E} 2, \mathrm{~T}, \mathrm{P} 4$ & $2 \mathrm{ml}$ & $200 \mu \mathrm{L}$ & $82-93$ & Non-Lethal & Guida et al., 2017 \\
\hline Amblyraja radiata & RIA & $\mathrm{P}$ & $\mathrm{E} 2, \mathrm{~T}$ & $5-10 \mathrm{~mL}$ & $400 \mu \mathrm{L}$ & $68-77$ & Lethal & Sulikowski et al., 2006 \\
\hline A. radiata & RIA & $\mathrm{P}$ & $\mathrm{E} 2, \mathrm{~T}, \mathrm{P} 4$ & $5-10 \mathrm{~mL}$ & - & $68-76$ & Lethal & Kneebone et al., 2007 \\
\hline A. radiata & RIA & $\mathrm{P}$ & $\mathrm{E} 2, \mathrm{~T}$ & $5-10 \mathrm{~mL}$ & - & - & Lethal & Sulikowski et al., 2007 \\
\hline Leucoraja erinacea & RIA & $\mathrm{P}$ & $\mathrm{E} 2, \mathrm{~T}, \mathrm{P} 4$ & - & $500 \mu \mathrm{L}$ & $81-94$ & Non-Lethal & Koob et al., 1986 \\
\hline L. erinacea & RIA & M, P & $\mathrm{E} 2, \mathrm{~T}, \mathrm{P} 4$ & $5 \mathrm{~g}, 8 \mathrm{~mL}$ & $2 \mathrm{~g}, 100 \mu \mathrm{L}$ & $74-91$ & Lethal & Prohaska et al., 2013b \\
\hline L. erinacea & RIA & $\mathrm{P}$ & E2, P4 & $5 \mathrm{~mL}$ & - & $75-76$ & Non-Lethal & Williams et al., 2013 \\
\hline Leucoraja ocellata & RIA & $\mathrm{P}$ & $\mathrm{E} 2, \mathrm{~T}, \mathrm{P} 4$ & $5-10 \mathrm{~mL}$ & $400 \mu \mathrm{L}$ & $68-76$ & Lethal & Sulikowski et al., 2004 \\
\hline L. ocellata & RIA & $\mathrm{P}$ & $\mathrm{E} 2, \mathrm{~T}$ & $5-10 \mathrm{~mL}$ & $400 \mu \mathrm{L}$ & $74-76$ & Lethal & Sulikowski et al., 2005 \\
\hline L. ocellata & RIA & $\mathrm{P}$ & $\mathrm{E} 2, \mathrm{~T}$ & $5-10 \mathrm{~mL}$ & $400 \mu \mathrm{L}$ & - & Lethal & Sulikowski et al., 2007 \\
\hline Malacoraja senta & RIA & $\mathrm{P}$ & $\mathrm{E} 2, \mathrm{~T}, \mathrm{P} 4$ & $5-10 \mathrm{~mL}$ & - & $77-88$ & Lethal & Kneebone et al., 2007 \\
\hline Raja eglanteria & RIA & $\mathrm{P}$ & E2, T, P4, DHT & $1-2 \mathrm{ml}$ & $500 \mu \mathrm{L}$ & $70-88$ & Non-Lethal & Rasmussen et al., 1999 \\
\hline T. marmorata & RIA & $\mathrm{P}, \mathrm{G}, \mathrm{H}$ & E2, T, P4, DHT & - & - & $85-90$ & Lethal & Fasano et al., 1992 \\
\hline Hypanus sabinus & RIA & $\mathrm{P}$ & $\mathrm{E} 2, \mathrm{~T}, \mathrm{P} 4, \mathrm{DHT}, \mathrm{CORT}$ & $5-10 \mathrm{~mL}$ & $500 \mu \mathrm{L}$ & $70-78$ & Lethal & Snelson et al., 1997 \\
\hline H. sabinus & RIA & $\mathrm{P}$ & $\mathrm{E} 2, \mathrm{~T}, \mathrm{P} 4, \mathrm{DHT}$ & - & $500 \mu \mathrm{L}$ & $70-88$ & Lethal & Tricas et al., 2000 \\
\hline H. sabinus & RIA & $\mathrm{P}$ & $\mathrm{E} 2, \mathrm{~T}$ & $5 \mathrm{~mL}$ & $500 \mu \mathrm{L}$ & $>78$ & Lethal & Gelsleichter et al., 2006 \\
\hline H. sabinus & RIA & $\mathrm{P}$ & CORT & - & $25-75 \mu \mathrm{L}$ & 89 & Lethal & Manire et al., 2007 \\
\hline Rhinoptera bonasus & RIA & $\mathrm{P}$ & $\mathrm{E} 2, \mathrm{~T}, \mathrm{P} 4, \mathrm{~A} 4$ & $1-3 \mathrm{ml}$ & - & $95-110$ & Non-Lethal & Sheldon et al., 2018 \\
\hline Urobatis halleri & RIA & $\mathrm{P}$ & $\mathrm{T}, 11-\mathrm{KT}$ & - & - & - & Lethal & Mull et al., 2008 \\
\hline U. halleri & RIA & $\mathrm{P}$ & $\mathrm{E} 2, \mathrm{~T}, \mathrm{P} 4$ & - & - & - & Lethal & Mull et al., 2010 \\
\hline Stegostoma fasciatum & EIA/ELISA & $\mathrm{P}$ & $\mathrm{E} 2, \mathrm{~T}, \mathrm{P} 4$ & - & - & - & Non-Lethal & Nozu et al., 2018 \\
\hline Rhincodon typus & EIA/ELISA & $\mathrm{Se}$ & E2, T, DHT & - & - & - & Lethal & Nozu et al., 2015 \\
\hline C. taurus & EIA/ELISA & $\mathrm{P}$ & $\mathrm{T}$ & $15 \mathrm{~mL}$ & $50 \mu \mathrm{L}$ & - & Non-Lethal & Wyffles et al., 2019 \\
\hline Prionace glauca & EIA/ELISA & $\mathrm{P}$ & P4, E2 & $5 \mathrm{~mL}$ & - & - & Lethal & Fujinami et al., 2020 \\
\hline
\end{tabular}




\begin{tabular}{|c|c|c|c|c|c|c|c|c|}
\hline R. terranovae & EIA/ELISA & $\mathrm{P}$ & $\mathrm{E} 2, \mathrm{~T}$ & $2 \mathrm{~mL}$ & - & - & Non-Lethal & Hoffmayer et al., 2010 \\
\hline T. marmorata & EIA/ELISA & $\mathrm{P}$ & $\mathrm{E} 2, \mathrm{P} 4$ & - & $100 \mu \mathrm{L}$ & 85 & Lethal & Prisco et al., 2008 \\
\hline Hypanus americanus & EIA/ELISA & $\mathrm{P}$ & $\mathrm{E} 2, \mathrm{~T}, \mathrm{P} 4, \mathrm{E} 1$ & - & $50 \mu \mathrm{L}$ & $94-108$ & Non-Lethal & Mylniczenko et al., 2019 \\
\hline Mobula alfredi & EIA/ELISA & $\mathrm{P}$ & $\mathrm{E} 2, \mathrm{~T}, \mathrm{P} 4, \mathrm{DHT}$ & - & - & - & Non-Lethal & Nozu et al., 2017 \\
\hline R. typus & TRFIA & $\mathrm{P}$ & $\mathrm{P} 4, \mathrm{E} 2$ & - & - & - & Non-Lethal & Matsumoto et al., 2019 \\
\hline S. acanthias & $\mathrm{PC}$ & $\mathrm{S}$ & DOC & - & - & - & Lethal & Simpson et al., 1963 \\
\hline S. acanthias & $\mathrm{PC}$ & $\mathrm{S}$ & DOC & $35 \mathrm{~g}$ & - & 65 & Lethal & Simpson et al., 1964 \\
\hline Scyliorhinus stellaris & TLC-GC & $\mathrm{S}$ & $\mathrm{T}, 17 \mathrm{P} 5$ & $19 \mathrm{~g}$ & - & 34 & - & Gottfried and Chieffi, 1967 \\
\hline Torpedo marmorata & TLC-GC & $\mathrm{P}$ & $\begin{array}{l}\text { T, P4, CORT, E, F, DOC, } \\
\text { E1, E3 }\end{array}$ & $5-12 \mathrm{~mL}$ & - & - & Lethal & Di Prisco et al., 1967 \\
\hline U. halleri & LC-MS/MS & $\mathrm{P}, \mathrm{H}$ & $\begin{array}{l}\text { E2, T, P4, 11-KT, E, } \\
\text { CORT, F, 17-OHP, S, } \\
\text { E1, E3, A4, 11-DHC }\end{array}$ & $10 \mathrm{~mL}$ & $50 \mu \mathrm{L}$ & - & Lethal & $\begin{array}{r}\text { Lyons and Wynne-Edwards, } \\
2018\end{array}$ \\
\hline
\end{tabular}




\section{Table 3 (on next page)}

Steroid hormones analysed for the study of chondrichthyan reproduction during 1963-2020. 
1 Table 3: Steroid hormones analysed for the study of chondrichthyan reproduction during 1963-2020.

\begin{tabular}{|c|c|c|c|}
\hline Hormones & Type & Analysed species & Number species \\
\hline 1 17ß-oestradiol (E2) & Oestrogen & All species in Table 1 & 34 \\
\hline 2 Testosterone $(\mathrm{T})$ & Androgen & All species in Table 1 & 34 \\
\hline 3 Progesterone (P4) & Progestogen & All species in Table 1; except $H$. colliei, $S$. stellaris & 33 \\
\hline $45 \alpha$-dihydrotestosterone (DHT) & Androgen & $\begin{array}{c}\text { R. typus, C. taurus, C. leucas, C. plumbeus, } N \text {. brevirostris, } S . \text { canicula, S. tiburo, } R \text {. } \\
\text { eglanteria, T. marmorata, } H . \text { sabinus, } M . \text { alfredi }\end{array}$ & 11 \\
\hline 5 11-ketotestosterone (11-KT) & Androgen & H. colliei, C. laticeps, S. canicula, S. tiburo, U. halleri & 7 \\
\hline 6 Corticosterone (CORT) & Glucocorticoid & N. brevirostris, S. tiburo, T. marmorata, H. sabinus, U. halleri & 7 \\
\hline 7 Estrone $(\mathrm{E} 1)$ & Oestrogen & S. canicula, T. marmorata, H. americanus, $U$. halleri & 4 \\
\hline 8 Androstenedione (A4) & Androgen & S. canicula, $R$. bonasus, $U$. halleri & 3 \\
\hline 9 Estriol (E3) & Oestrogen & T. marmorata, U. halleri & 2 \\
\hline 10 17-hydroxyprogesterone (17-OHP) & Progestogen & S. canicula, U. halleri & 2 \\
\hline 11 11-deoxycorticosterone (DOC) & Mineralocorticoid & S. acanthias, T. marmorata & 2 \\
\hline 12 Cortisol (F) & Glucocorticoid & T. marmorata, $U$. halleri & 2 \\
\hline 13 Cortisone $(\mathrm{E})$ & Glucocorticoid & T. marmorata, U. halleri & 2 \\
\hline 14 11-deoxycortisol (S) & Glucocorticoid & U. halleri & 1 \\
\hline 15 Dihydroprogesterone (DHP) & Progestogen & S. tiburo & 1 \\
\hline 16 17-hydroxypregnenolone (17P5) & Progestogen & S. stellaris & 1 \\
\hline 17 11-ketoandrostenedione (11KA4) & Androgen & S. tiburo & 1 \\
\hline $185 \alpha$-androstane- $3 \alpha, 17 \beta$-diol ( $3 \alpha$-diol) & Androgen & S. canicula & 1 \\
\hline 19 11-dehydrocorticosterone (11-DHC) & Mineralocorticoid & U. halleri & 1 \\
\hline
\end{tabular}




\section{Table 4 (on next page)}

Steroid hormones analysed per chondrichthyan species during 1963-2020.

Abbreviations: $17 \beta$-oestradiol (E2); testosterone (T); progesterone (P4); $5 \alpha-$

dihydrotestosterone (DHT); 11-ketotestosterone (11-KT); corticosterone (CORT);

androstenedione (A4); 17-hydroxyprogesterone (17-OHP); estrone (E1); estriol (E3); cortisone

(E); cortisol (F); 11-deoxycortisol (S); dihydroprogesterone (DHP); 11 deoxycorticosterone

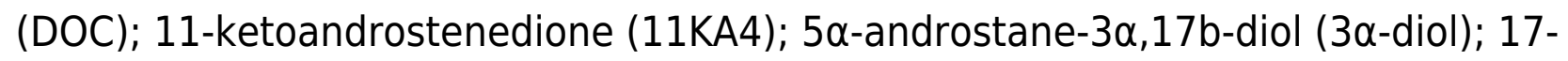

hydroxypregnenolone (17P5); 11-dehydrocorticosterone (11-DHC). 
Table 4: Steroid hormones analysed per chondrichthyan species during 1963-2020.

2 Abbreviations: 17ß-oestradiol (E2); testosterone (T); progesterone (P4); 5a-dihydrotestosterone (DHT); 11-ketotestosterone (11-KT); corticosterone (CORT); androstenedione (A4); 17-hydroxyprogesterone (17-OHP); estrone (E1); estriol (E3); cortisone (E); cortisol (F); 11deoxycortisol (S); dihydroprogesterone (DHP); 11 deoxycorticosterone (DOC); 11-ketoandrostenedione (11KA4); 5a-androstane-3a,17b-diol (3adiol); 17-hydroxypregnenolone (17P5); 11-dehydrocorticosterone (11-DHC).

\begin{tabular}{|c|c|c|c|c|c|c|c|c|c|c|c|c|c|c|c|c|c|c|c|}
\hline Species & E2 & $\mathrm{T}$ & P4 & DHT & $11-\mathrm{KT}$ & CORT & E1 & A4 & E3 & 17-OHP & DOC & $\mathrm{F}$ & $\mathrm{E}$ & $\mathrm{S}$ & DHP & $17 \mathrm{P} 5$ & $11 \mathrm{KA} 4$ & $3 \alpha$-diol & 11-DHC \\
\hline Hydrolagus colliei & $\bullet$ & $\bullet$ & - & - & $\bullet$ & - & - & - & - & - & - & - & - & - & - & - & - & - & - \\
\hline Notorynchus cepedianus & $\bullet$ & $\bullet$ & $\bullet$ & - & - & - & - & - & - & - & - & - & - & - & - & - & - & - & - \\
\hline Centroscymnus coelolepis & $\bullet$ & $\bullet$ & $\bullet$ & - & - & - & - & - & - & - & - & - & - & - & - & - & - & - & - \\
\hline Squalus acanthias & $\bullet$ & $\bullet$ & $\bullet$ & - & - & - & - & - & - & - & $\bullet$ & - & - & - & - & - & - & - & - \\
\hline Chiloscyllium plagiosum & $\bullet$ & $\bullet$ & $\bullet$ & - & - & - & - & - & - & - & - & - & - & - & - & - & - & - & - \\
\hline Hemiscyllium ocellatum & $\bullet$ & $\bullet$ & $\bullet$ & - & - & - & - & - & - & - & - & - & - & - & - & - & - & - & - \\
\hline Rhincodon typus & $\bullet$ & $\bullet$ & $\bullet$ & $\bullet$ & - & - & - & - & - & - & - & - & - & - & - & - & - & - & - \\
\hline Stegostoma fasciatum & $\bullet$ & $\bullet$ & $\bullet$ & - & - & - & - & - & - & - & - & - & - & - & - & - & - & - & - \\
\hline Carcharodon carcharias & $\bullet$ & $\bullet$ & $\bullet$ & - & - & - & - & - & - & - & - & - & - & - & - & - & - & - & - \\
\hline Carcharias taurus & $\bullet$ & $\bullet$ & $\bullet$ & $\bullet$ & - & - & - & - & - & - & - & - & - & - & - & - & - & - & - \\
\hline Carcharhinus leucas & $\bullet$ & $\bullet$ & $\bullet$ & $\bullet$ & - & - & - & - & - & - & - & - & - & - & - & - & - & - & - \\
\hline Carcharhinus plumbeus & $\bullet$ & $\bullet$ & $\bullet$ & $\bullet$ & - & - & - & - & - & - & - & - & - & - & - & - & - & - & - \\
\hline Galeocerdo cuvier & $\bullet$ & $\bullet$ & $\bullet$ & - & - & - & - & - & - & - & - & - & - & - & - & - & - & - & - \\
\hline Negaprion brevirostris & $\bullet$ & $\bullet$ & $\bullet$ & $\bullet$ & - & $\bullet$ & - & - & - & - & - & - & - & - & - & - & - & - & - \\
\hline Prionace glauca & $\bullet$ & - & $\bullet$ & - & - & - & - & - & - & - & - & - & - & - & - & - & - & - & - \\
\hline Rhizoprionodon taylori & $\bullet$ & $\bullet$ & $\bullet$ & - & - & - & - & - & - & - & - & - & - & - & - & - & - & - & - \\
\hline $\begin{array}{l}\text { Rhizoprionodon } \\
\text { terranovae }\end{array}$ & $\bullet$ & $\bullet$ & $\bullet$ & - & - & - & - & - & - & - & - & - & - & - & - & - & - & - & - \\
\hline Cephalloscyllium laticeps & $\bullet$ & $\bullet$ & $\bullet$ & - & $\bullet$ & - & - & - & - & - & - & - & - & - & - & - & - & - & - \\
\hline Scyliorhinus canicula & $\bullet$ & $\bullet$ & $\bullet$ & $\bullet$ & $\bullet$ & - & $\bullet$ & $\bullet$ & - & $\bullet$ & - & - & - & - & - & - & - & $\bullet$ & - \\
\hline Scyliorhinus stellaris & $\bullet$ & $\bullet$ & - & - & - & - & - & - & - & - & - & - & - & - & - & $\bullet$ & - & - & - \\
\hline Sphyrna tiburo & $\bullet$ & $\bullet$ & $\bullet$ & $\bullet$ & $\bullet$ & $\bullet$ & - & - & - & - & - & - & - & - & $\bullet$ & - & $\bullet$ & - & - \\
\hline Mustelus schmitti & $\bullet$ & $\bullet$ & $\bullet$ & - & - & - & - & - & - & - & - & - & - & - & - & - & - & - & - \\
\hline Trygonorrhina dumerilii & $\bullet$ & $\bullet$ & $\bullet$ & - & - & - & - & - & - & - & - & - & - & - & - & - & - & - & - \\
\hline Amblyraja radiata & $\bullet$ & $\bullet$ & $\bullet$ & - & - & - & - & - & - & - & - & - & - & - & - & - & - & - & - \\
\hline Leucoraja erinacea & $\bullet$ & $\bullet$ & $\bullet$ & - & - & - & - & - & - & - & - & - & - & - & - & - & - & - & - \\
\hline Leucoraja ocellata & $\bullet$ & $\bullet$ & $\bullet$ & - & - & - & - & - & - & - & - & - & - & - & - & - & - & - & - \\
\hline Malacoraja senta & $\bullet$ & $\bullet$ & $\bullet$ & - & - & - & - & - & - & - & - & - & - & - & - & - & - & - & - \\
\hline Raja eglanteria & $\bullet$ & $\bullet$ & $\bullet$ & $\bullet$ & - & - & - & - & - & - & - & - & - & - & - & - & - & - & - \\
\hline Torpedo marmorata & $\bullet$ & $\bullet$ & $\bullet$ & $\bullet$ & - & $\bullet$ & $\bullet$ & - & $\bullet$ & - & $\bullet$ & $\bullet$ & $\bullet$ & - & - & - & - & - & - \\
\hline Hypanus sabinus & $\bullet$ & $\bullet$ & $\bullet$ & $\bullet$ & - & $\bullet$ & - & - & - & - & - & - & - & - & - & - & - & - & - \\
\hline
\end{tabular}


Hypanus americanus

Mobula alfredi

Rhinoptera bonasus

Urobatis halleri

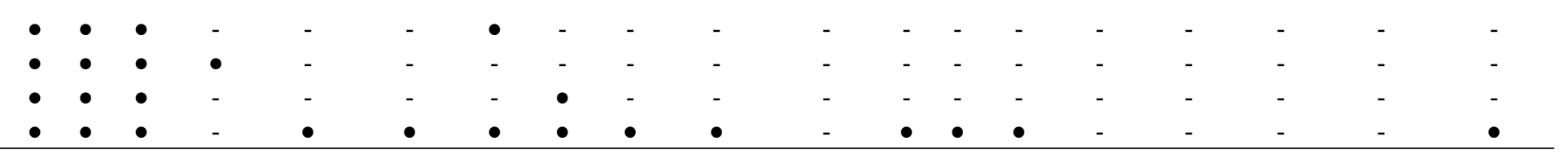

